Review

\title{
Traumatic Brain Injury Pathophysiology and Treatments: Early, Intermediate, and Late Phases Post-Injury
}

\section{Hanna Algattas ${ }^{1, *}$ and Jason H. Huang ${ }^{2}$}

1 School of Medicine and Dentistry, University of Rochester Medical Center, 601 Elmwood Ave, Box 441, Rochester, NY 14642, USA

2 School of Medicine and Dentistry, University of Rochester Medical Center, 601 Elmwood Ave, Box 670, Rochester, NY 14642, USA; E-Mail: jason_huang@urmc.rochester.edu

* Author to whom correspondence should be addressed; E-Mail: hanna_algattas@urmc.rochester.edu; Tel.: +1-315-884-3572.

Received: 10 November 2013; in revised form: 2 December 2013 / Accepted: 20 December 2013 / Published: 30 December 2013

\begin{abstract}
Traumatic Brain Injury (TBI) affects a large proportion and extensive array of individuals in the population. While precise pathological mechanisms are lacking, the growing base of knowledge concerning TBI has put increased emphasis on its understanding and treatment. Most treatments of TBI are aimed at ameliorating secondary insults arising from the injury; these insults can be characterized with respect to time post-injury, including early, intermediate, and late pathological changes. Early pathological responses are due to energy depletion and cell death secondary to excitotoxicity, the intermediate phase is characterized by neuroinflammation and the late stage by increased susceptibility to seizures and epilepsy. Current treatments of TBI have been tailored to these distinct pathological stages with some overlap. Many prophylactic, pharmacologic, and surgical treatments are used post-TBI to halt the progression of these pathologic reactions. In the present review, we discuss the mechanisms of the pathological hallmarks of TBI and both current and novel treatments which target the respective pathways.
\end{abstract}

Keywords: Traumatic Brain Injury (TBI); inflammation; seizure; excitotoxicity; treatment 


\section{Introduction}

Individuals of all ages, background, and health status are susceptible to traumatic brain injury (TBI). Every year in the United States 1.7 million people suffer TBI and TBI is listed as a contributing cause in approximately one third of injury-related deaths [1]. While the numbers suggest a grim state concerning TBI treatment there have been improvements in its management. Over the past 30 years, deaths from severe TBI have reduced from $50 \%$ to fewer than $25 \%$ [2]. Evidence-based guidelines for TBI management were introduced in 1995 because of varied treatment approaches but in the years following there have still been lapses in consistent implementation [3,4]. One problem in the development of reliable guidelines for treatment of TBI is the varied pathophysiology of injury. TBI may be penetrating or non-penetrating, diffuse or focal, vary in severity, location, and patient characteristics, just to name a few. Additionally, since TBI is often accident-related, there are limited primary prophylactic measures. Much of the resultant acute and chronic harm from TBI is related to secondary generation of tissue damage and inflammation.

In the present review, we will attempt to describe the pathophysiology of three distinct yet over-lapping states post-injury, the early, immediate, and late phases. The early phase of damage usually occurs within $24 \mathrm{~h}$ of injury and is directly related to tissue damage and deregulated physiological functions, the intermediate phase takes place in the days following TBI and entails neuroinflammation, and the late phase is primarily associated with seizures and epileptogenesis and arises days to weeks after TBI. Following each phase we will describe current and novel treatments and interventions that directly target the pathophysiology of each phase. There is a wealth of TBI data with countless views on injury mechanisms and treatment modalities; thus, this review provides a detailed but limited glimpse into components of the literature.

\section{Early Phase}

Different forms of mechanical insult ensue depending on the type of TBI, including acceleration-deceleration shearing and penetrating injury. Regardless, early damage following TBI often stems from the ischemic cascade. There is a fine interplay regarding normal energy processes and disruption of this intricate path leads to decreased glucose utilization, lactic acid accumulation, reduced ATP and activity of ATP-reliant ion pumps, $\mathrm{Ca}^{2+}$-induced depolarization, excitotoxicity, and cellular death. The sequential ischemic cascade begins with interruption of normal blood flow and numerous experimental studies demonstrate this effect. As expected, rodents subject to penetrating ballistic-like brain injury (PBBI) display a 70\% reduction in regional cerebral blood flow (CBF) ipsilateral to the injury as compared to baseline. PBBI also decreases brain tissue oxygenation tension and causes spreading cortical depolarizations shortly after injury [5]. CBF reductions are more pronounced in older compared to younger rodents, as seen with fluid percussion injury (FPI) TBI [6]. As mentioned earlier, there is overlap between pathological phases. For instance, clinical evidence has demonstrated chronic $\mathrm{CBF}$ reduction in particular brain regions of TBI patients which cause a lasting effect to normal functioning [7]. Indeed a small study with xenon computed tomography (CT) found CBF measurement within the first $12 \mathrm{~h}$ post-TBI to predict six month Glasgow Outcome Scale (GOS) 
values, although the authors insist a larger RCT trial is warranted [8]. Overall, the literature suggests $\mathrm{CBF}$ disturbance is one of the first pathological steps and the effect varies with age and time.

Compared to the rest of the body, the brain displays an extremely tight autoregulation of blood flow and any perturbance alters the brain's normal metabolic landscape. In another PBBI model, injury reduced brain oxygen tension by $40 \%$ in the area encompassing the lesion compared to sham rats, and oxygen tension was positively correlated with fraction of inspired oxygen in the air, ranging from 21\%-35\% [9]. Oddo et al. (2012) examined brain oxygen tension in anemia patients who suffered TBI. Those anemic patients with compromised brain oxygen tension were over six times more likely to suffer unfavorable outcomes, regardless of the injury severity; suggesting proper oxygenation minimizes damage due to injury [10]. The data may be extrapolated into the clinical realm where they become especially relevant. Guidelines from the Brain Trauma Foundation promote the use of intracranial pressure (ICP) and cerebral perfusion pressure (CPP) monitoring techniques when managing TBI patients [11]. Yet, Eriksson et al. (2012) was quick to reveal data suggesting that ICP and CPP pressure monitoring should not be substituted for true measures of brain tissue oxygenation because oxygenation is an independent value [12].

Reduced blood flow and oxygen metabolism in the brain promotes a metabolic switch from the usual aerobic process to an anaerobic program. Lactate is a marker of anaerobic respiration and builds up in tissue deprived of oxygen. Many studies have used measures of glucose consumption or oxygen levels prove there is a reduction in normal cerebral metabolism [13,14]. Even if other vital measures are controlled, metabolic deregulation still occurs. For instance, among 76 successfully resuscitated TBI patients with managed ICP, $76 \%$ had decreased glucose and $93 \%$ had an elevated lactate/pyruvate ratio [15]. Not only might cerebral blood flow and oxygen affect metabolic functioning but also the ability for glucose to enter the brain. One study using positron emission tomography (PET) with radioactively tagged glucose demonstrated diminished uptake of glucose into both cerebral hemispheres after FPI; further, glial activation and axonal damage seemed to persist in regions deprived of glucose uptake [16]. In later phases of TBI pathophysiology, large variations in glucose levels have been associated with worse long-term outcomes, suggesting a more complicated metabolic relationship [17]. Interestingly, glucose administration after controlled-cortical impact (CCI) is neuroprotective in the hippocampus and cortex, suggesting exogenous glucose supplementation is beneficial post-TBI [18]. On the other hand, lactate is found elevated in microdialysates of patients with acute TBI but lactate nor lactate/pyruvate ratio seemed to be associated with brain hypoxia [19]. Similar results have been seen in severe TBI, suggesting lactate's increased post-TBI is not due to ischemic factors [20]. The variation in the literature paint a confusing metabolic landscape which likely varies based on the heterogeneity of TBI and time period of analysis.

Deregulated cerebral metabolism and the favored breakdown of lactate rather than glucose necessarily lead to a deficit in cerebral energy production [21]. Subsequently, reductions in ATP lead to the failure of ATP-dependent ion channels and proteins [22]. Ischemia, reduced CBF, and altered metabolic function ultimately lead to excitotoxicity-mediated cell death, including both apoptosis and necrosis [23,24]. Early research on a cohort of TBI patients identified elevated excitatory amino acids in microdialysates of patients, at levels 50 times normal in approximately $30 \%$ of the patients; correlations between excitatory amino acid quantity and secondary brain damage was also noted [25]. Glutamate is the prime excitatory amino acid and is released via pre-synaptic vesicles or leaks out of 
damaged membranes after TBI. Glutamate elevates because of $\mathrm{Ca}^{2+}$-mediated release and decreased glial glutamate uptake [26]. Such glutamate release also correlates with age, being elevated in microdialysates of elderly TBI patients compared to their younger TBI counterparts; in the same study, other measures such as some cytokines had no quantitative change [27].

Studies in vitro confirmed elevated glutamate activity leads to hyperexcitability and neuronal death in a dose-response relationship [28]. Mechanistically, excess glutamate binds the NMDA receptor and promotes a massive influx of $\mathrm{Ca}^{2+}$ and $\mathrm{Na}^{+}$leading to activation of a number of enzymes responsible for ensuing cellular damage; astrocytes are prone to excitotoxicity-mediated cell death as well [29]. Indeed, administration of amantadine, an NMDA receptor antagonist, to FPI rats improved performance in the Morris Water Maze (MWM) and promoted neuronal survival in CA2/CA3 pyramidal neurons of the hippocampus [30]. These findings are in agreement with other research where MK-801, an NMDA receptor antagonist, decreased neuronal caspase-3 expression, neuronal nitric oxide synthase (nNOS) positive neurons, and mitochondria degeneration [31]. The synthesis of nitric oxide (NO) relies on $\mathrm{Ca}^{2+}$ to an extent and its upregulation can lead to significant oxidative damage post-TBI [32]. Recent evidence suggests metabolites of NO could be reliable markers for severe TBI [33]. NO is a direct component of the neuroinflammatory cascade, intriguingly glutamate indirectly promotes inflammatory processes as well. Dai et al. (2010) demonstrated that adequately high concentration of glutamate switched the effect of the adenosine-adenosine $\mathrm{A}(2 \mathrm{~A})$ receptor from anti-inflammatory to pro-inflammatory [34]. Overall, it is well accepted that glutamate opens the proverbial flood gates of the cell which produce significant cellular harm.

Intracellular accumulation of $\mathrm{Ca}^{2+}$ due to glutamate excitotoxicity perturbs intracellular ionic concentrations and warrants mitochondria to sequester such elevated $\mathrm{Ca}^{2+}$ stores [35]. Isolated mitochondria from CCI experimental models demonstrate increased $\mathrm{Ca}^{2+}$ stores and impaired oxidative phosphorylation, another process causing metabolic deregulation post-TBI [36]. Influx of $\mathrm{Ca}^{2+}$ into mitochondria promotes production of reactive oxygen species (ROS) which cause additional damage at elevated levels [37]. Structurally, mitochondria exhibit swelling due to a mitochondrial permeability transition pore that compromises their function. Experimental findings demonstrated mitochondrial pathology precedes neuronal loss and can be seen as early as 30 min post-TBI in CCI rats [38]. Bouts of $\mathrm{Ca}^{2+}$ stress to mitochondria lead to release of cytochrome $\mathrm{c}$ from mitochondrial membranes and the activation of caspase, a protein involved in cell death pathways. Of clinical relevance, both cytochrome $\mathrm{c}$ and caspase have been identified in the CSF of patients with severe TBI [39]. Clinical evidence corroborates the importance of mitochondrial pathology since $\mathrm{N}$-acetylaspartate, a surrogate of mitochondrial function, is correlated with TBI patient outcomes [40]. Overall, immediate physical and structural damage from TBI interrupts blood flow and oxygenation to the brain which are both tightly regulated variables. Mechanical stress and ischemia help advance the excitotoxic cascade and deregulate cerebral metabolism, producing the earliest pathological indications of TBI.

\section{Prophylactic Hypothermia and Hyperbaric Oxygen Therapy (HBOT)}

Initial management of the TBI patient is generally centered on prophylaxis and supportive measures, including blood pressure and oxygenation monitoring, infection and deep vein thrombosis prophylaxis, analgesia, and setting thresholds on vital values including ICP and CPP. Deregulation of 
cerebral metabolism, blood flow, and lost perfusion are early changes post-TBI. Prophylactic hypothermia is one option that directly combats the problematic nature of early TBI pathology. Hypothermia lowers cerebral metabolic rates and slows damage occurring post-TBI. For every degree Celsius decrease in temperature, brain oxygen consumption drops $5 \%-7 \%$; this is capable of decreasing brain energy expenditure while maintaining blood oxygenation levels, therefore matching cerebral metabolism with the reduced cerebral blood flow [41]. Hypothermia also dampens the innate immune response post-TBI in experimental models, also demonstrating the overlap with inflammatory phase which is yet to be discussed [42]. The Brain Trauma Foundation (BTF) guidelines for severe TBI treatment posit as level III evidence that hypothermia patients do not exhibit decreased mortality compared to normothermic controls. Simultaneously, the BTF reports preliminary evidence which suggests a decrease in mortality upon maintaining target temperatures for $48 \mathrm{~h}$ and that patients receiving prophylactic hypothermia had higher Glasgow Outcome Scale (GOS) scores compared to normothermic patients [43].

Prophylactic hypothermia has received mixed results in the literature because of multiple variables involved in its successful implementation; these include temperature at time of injury, initial onset of cooling, rate of cooling, final temperature sought, and mechanism of cooling. Early research corroborated such variability by finding spontaneous hypothermia upon time of admission to be associated with poorer prognosis [44-46]. Thus, it may be said that hypothermia administration is as heterogeneous as the TBI pathology itself. Since brain temperature cannot be predicted with high confidence from body temperatures separate monitoring is recommended [47]. The National Acute Brain Injury Study: Hypothermia II was a large scale RCT which failed to confirm any benefit of hypothermia [48]. However, recent retrospective analysis of pooled neurotrauma data revealed patients receiving hypothermia treatment had significantly higher favorable outcomes compared to normothermic patients and those with no temperature management; it is important to note that hypothermic patients were, on average, significantly younger [49]. Indeed, other studies have replicated these findings. One such study demonstrated hypothermia of $32.7^{\circ} \mathrm{C}$ for $72 \mathrm{~h}$ produced favorable outcomes [50]. The same study also identified hyperglycemia to be an independent risk for poor outcome and that hypothermic patients had reduced glucose concentrations compared to normothermic counterparts. Such a finding suggests hypothermia may promote favorable outcomes by decreased glucose levels. A meta-analysis by Fox et al. (2010) suggests a rationale for discrepancies among the literature. That group found hypothermia studies with long-term/goal-directed strategies in their design concluded patients to have lower mortality and more favorable outcome whereas studies implementing short-term strategies were often inconclusive (Table 1) [51]. Besides strategic design, another key variable influencing prophylactic hypothermia studies is re-warming strategy. For instance, the National Acute Brain Injury Study: Hypothermia II re-warmed patients from $33{ }^{\circ} \mathrm{C}$ by $0.5{ }^{\circ} \mathrm{C}$ every two hours which found no difference in GOS or mortality between hypothermic and normothermic patients [48]. Another prospective study cooled patients to $32.7^{\circ} \mathrm{C}$ and allowed them to spontaneously re-warm at room temperature. Importantly, that study found hypothermic patients to have significantly improved GOS compared to the normothermic group [50]. Undoubtedly then, re-warming strategies may be just as significant as cooling ones in optimizing patient outcomes. 
Table 1. Prophylactic Hypothermia Evidence in Traumatic Brain Injury (TBI). Table 1 summarizes results of evidence regarding the effect of prophylactic hypothermia on various outcomes. The selected results contain mixed results regarding the effectiveness of TBI. * = Study as cited in text.

\begin{tabular}{|c|c|c|c|c|}
\hline Study & Design & $\begin{array}{l}\text { Primary } \\
\text { Outcome }\end{array}$ & Results & Notes \\
\hline $\begin{array}{l}\text { Bukur et al. } \\
2012 *[45]\end{array}$ & Retrospective & $\begin{array}{l}\text { Spontaneous } \\
\text { admission } \\
\text { hypothermia } \\
\text { on mortality }\end{array}$ & $\begin{array}{l}\text { Pre-hospital hypothermia } \\
\text { associated with increased } \\
\text { mortality (Adjusted OR }=2.5 \text { ) }\end{array}$ & $\begin{array}{l}95 \% \mathrm{CI}=1.1-6.3 \\
p=0.04 \\
44 \text { hypothermic patients } \\
1790 \text { normothermic } \\
\text { patients }\end{array}$ \\
\hline $\begin{array}{l}\text { Rubiano et } \\
\text { al. } 2013 * \\
{[46]}\end{array}$ & $\begin{array}{l}\text { Secondary analysis of } \\
\text { Pennsylvania Trauma } \\
\text { Outcome Study } \\
\text { (PTOS) }\end{array}$ & $\begin{array}{l}\text { Spontaneous } \\
\text { admission } \\
\text { hypothermia } \\
\text { on mortality }\end{array}$ & $\begin{array}{l}\text { Odds of death increased in } \\
\text { spontaneous hypothermia group } \\
(\mathrm{OR}=1.70)\end{array}$ & $\begin{array}{l}95 \% \mathrm{CI}=1.50-1.93 \\
\text { Odds adjusted for } \\
\text { demographics, injury } \\
\text { characteristics, and } \\
\text { information at admission }\end{array}$ \\
\hline $\begin{array}{l}\text { Clifton et } \\
\text { al. } 2011 * \\
{[48]}\end{array}$ & $\begin{array}{l}\text { Randomized } \\
\text { controlled trial (RCT); } \\
\text { National Acute Brain } \\
\text { Injury Study: } \\
\text { Hypothermia II } \\
\text { (NABIS: H II) }\end{array}$ & $\begin{array}{l}\text { Glasgow } \\
\text { outcome } \\
\text { scale (GOS) } \\
\text { at } 6 \text { months } \\
\text { post-injury }\end{array}$ & $\begin{array}{l}\text { GOS nor mortality significantly } \\
\text { differed between hypothermia and } \\
\text { normothermia groups }\end{array}$ & $\begin{array}{l}\text { Cooled to } 33^{\circ} \mathrm{C} \text { for } \\
48 \mathrm{~h} \text { and rewarmed } \\
0.5^{\circ} \mathrm{C} \text { every } 2 \mathrm{~h} \text {. } \\
\text { Normothermia } \\
\text { maintained at } 37^{\circ} \mathrm{C}\end{array}$ \\
\hline $\begin{array}{l}\text { Suehiro et } \\
\text { al. } 2013 * \\
\text { [49] }\end{array}$ & $\begin{array}{l}\text { Retrospective analysis } \\
\text { of Japan Neurotrauma } \\
\text { Data Bank Project } \\
(2009)\end{array}$ & GOS & $\begin{array}{l}\text { Hypothermia group had } \\
\text { significantly more favorable } \\
\text { outcomes compared with } \\
\text { normothermia and no temperature } \\
\text { management groups }\end{array}$ & $\begin{array}{l}\text { Favorable outcomes- } \\
\text { hypothermia }(52.4 \%) \text {, } \\
\text { normothermia }(26.9 \%) \text {, } \\
\text { No temperature } \\
\text { management }(20.7 \%)\end{array}$ \\
\hline $\begin{array}{l}\text { Zhao et al. } \\
2011 *[50]\end{array}$ & $\begin{array}{l}\text { Prospective } \\
\text { randomized trial }\end{array}$ & GOS & $\begin{array}{l}\text { Hypothermia group had improved } \\
\text { outcome }(75.0 \%) \text { compared to } \\
\text { normothermia }(51.2 \%)\end{array}$ & $\begin{array}{l}p=0.038 \text { Hypothermia } \\
\text { maintained at } 32.7^{\circ} \mathrm{C} \text { for } \\
72 \mathrm{~h} \text {. Spontaneous } \\
\text { rewarming at room } \\
\text { temperature. } \\
\text { Normothermia } \\
\text { maintained at } 37^{\circ} \mathrm{C}\end{array}$ \\
\hline
\end{tabular}

Pairing hypothermia with other treatment strategies may accentuate benefits. For example, concurrent monitoring of brain tissue oxygen and administration of mild hypothermia synergistically assists in reducing ICP post-TBI; decreasing ICP may limit inflammatory damage occurring later in TBI pathogenesis [52]. Identifying cases of TBI where the use of hypothermia is warranted is vital. In agreement with previously mentioned data, xenon- and perfusion-CT analyses demonstrated disturbances in cerebral blood flow (CBF) in TBI patients [53]. In that study, Honda et al. (2013) found $\mathrm{CBF}$ in focal TBI patients to be more perturbed than in diffuse TBI [53]. The research group suggested moderate hypothermia should be used in managing cases of TBI involving larger CBF changes. Of extreme clinical importance, data from pediatric TBI patients demonstrated that phenytoin elimination is decreased after hypothermia administration, and this is especially important because 
phenytoin is a recommended anti-epileptic used in the treatment of acute post-traumatic seizures and has non-linear metabolic characteristics [54]. Ultimately, the potential for widespread use of hypothermia is possible but requires more research. Trials to continue examination of hypothermia's therapeutic potential are underway, including a multi-center trial by Andrews et al. (2013) and the POLAR-RCT in Australia and New Zealand [55].

Hyperbaric oxygen therapy (HBOT) is another intervention used in early prophylactic treatment of TBI. HBOT encompasses the inhalation of $100 \%$ oxygen at environmental pressures above one atmosphere. As spoken to earlier, deregulation of $\mathrm{CBF}$ produces an oxygen deficit causing metabolic modifications and ischemia. By increasing the partial pressure of oxygen in blood, independent of that bound to hemoglobin in erythrocytes, HBOT increases oxygen saturation reaching the brain and attempts to decrease tissue damage secondary to ischemia and hypoxia [56]. Yet, since most $\mathrm{O}_{2}$ is hemoglobin-bound, HBOT-mediated $\mathrm{O}_{2}$ saturation increase is limited to up to $10 \%$; a clinically significant amount in many cases. Small scale, early research proved treatment with $100 \%$ oxygen for six hours reduced lactate and increased brain tissue oxygenation [57]. More extensive evidence from an early systematic review deemed HBOT's therapeutic benefit inconclusive [58]. Yet, a recent retrospective study found TBI patients treated with HBOT have improved outcomes when compared to control counterparts [59]. Additionally, prospective studies administering HBOT after patients' conditions stabilized also demonstrated improved outcomes based on GCS and GOS [60]. One large clinical trial examined the efficacy of HBOT followed by normobaric hyperoxia treatment (NBH) for three days and found the treatment group had reductions in ICP, mortality, and cerebral toxicity with improved favorable GOS outcomes [61]. In an earlier study, Rockswold et al. (2010) compared HBOT to NBH and demonstrated the effects of both to be very similar compared to a standard care control group (Table 2) [62].

Variations in HBOT administration and TBI circumstances may alter outcomes. In mild TBI, HBOT did not significantly differ from a sham treatment when analyzing post-concussive symptoms, suggesting an injury severity interaction [63]. Still, the study by Wolf et al. (2012) used 2.4 ATA HBOT whereas 1.5 ATA HBOT in chronic blast-induced mild to moderate military TBI patients improved symptoms and cognitive outcomes, suggesting an administration interaction [64]. With mounting evidence, HBOT may become a treatment for targeted types of TBI. For instance, regional $\mathrm{CBF}$ measurements in healthy controls provided HBOT revealed that blood flow was increased to specific areas, including cerebellum, sensory-motor, premotor, visual, and posterior cingulate cortices compared to normoxic patients. Interestingly, normoxic patients had increased CBF to many subcortical structures, including the hippocampus [65]. Thus, the data suggest identifying regions of deregulated CBF before administering HBOT may be beneficial. Lastly, it is essential to be mindful of the adverse effects of hyperoxic treatments. For instance, hyperoxia in healthy patients has been shown to produce a small decrease in CBF owing to vasoconstriction of vasculature [66]. Experimental studies suggest hyperoxic treatments may increase free radical oxygen species generation [67]. However, the findings have been double-edged; Puccio et al. (2009) did not find significantly altered oxidative stress markers in the CSF of TBI patients after a two hour stint of normobaric hyperoxia [68]. Overall, the present evidence provides conclusions on both sides of the spectrum regarding HBOT. Indeed, understanding the pathophysiology of TBI and the specific patient's case provides insight into when HBOT may be clinically indicated. 
Table 2. Hyperbaric Oxygen Therapy Evidence in TBI. Table 2 summarizes varied evidence regarding the use of Hyperbaric Oxygen Therapy (HBOT) in the treatment of TBI and its effect on various primary outcomes. The selected evidence displays mixed results concerning the therapeutic benefit of HBOT. * = Study as cited in text.

\begin{tabular}{|c|c|c|c|c|}
\hline Study & Design & Primary Outcome & Results & Notes \\
\hline $\begin{array}{l}\text { McDonagh et al. } \\
2004 *[58]\end{array}$ & $\begin{array}{l}\text { Systematic } \\
\text { review }\end{array}$ & Study outcome & $\begin{array}{l}\text { Two studies demonstrated a } \\
\text { benefit to HBOT. Five } \\
\text { observational studies did not } \\
\text { yield effective evidence }\end{array}$ & \\
\hline $\begin{array}{l}\text { Sahni et al. } \\
2012 *[59]\end{array}$ & Retrospective & $\begin{array}{l}\text { Rancho Los Amigos } \\
\text { Scale (RLAS) }\end{array}$ & $\begin{array}{l}\text { Improved cognitive function } \\
\text { in HBOT group (RLAS) }\end{array}$ & $\begin{array}{l}\text { HBOT and standard } \\
\text { treatment groups each } \\
\text { had } 20 \text { patients }\end{array}$ \\
\hline $\begin{array}{l}\text { Lin et al. } \\
2008 *[60]\end{array}$ & $\begin{array}{l}\text { Prospective } \\
\text { randomized } \\
\text { trial }\end{array}$ & GCS GOS & $\begin{array}{l}\text { HBOT group had higher } \\
\text { GCS improvement } \\
(p<0.05) \text {; HBOT group } \\
\text { had significant } \\
\text { GOS improvement }\end{array}$ & $\begin{array}{l}\text { HBOT and standard } \\
\text { treatment groups each } \\
\text { had } 22 \text { patients. GCS } \\
\text { and GOS measured } \\
\text { before HBOT and } \\
\text { 3-6 months after }\end{array}$ \\
\hline $\begin{array}{l}\text { Rockswold et al. } \\
2013 *[61]\end{array}$ & Phase II RCT & $\begin{array}{l}\text { Sliding } \\
\text { dichotomized GOS } \\
\text { and mortality }\end{array}$ & $\begin{array}{l}26 \% \text { reduction in mortality } \\
(p=0.0048) \text { and } 36 \% \\
\text { improvement in favorable } \\
\text { GOS ( } p=0.024) \text { as } \\
\text { compared to control }\end{array}$ & $\begin{array}{l}\text { Treatment group given } \\
\text { HBOT for } 60 \mathrm{~min} \text { at } \\
1.5 \mathrm{~atm} \text { followed by } \\
\text { normobaric hyperoxia } \\
\left(3 \mathrm{~h} \text { of } 100 \% \mathrm{O}_{2} \text { at }\right. \\
1.0 \mathrm{~atm})\end{array}$ \\
\hline $\begin{array}{l}\text { Rockswold et al. } \\
2010 *[62]\end{array}$ & $\begin{array}{l}\text { Prospective } \\
\text { randomized } \\
\text { trial }\end{array}$ & $\begin{array}{l}\text { Metabolic markers } \\
(\mathrm{CSF} \text { lactate, } \\
\text { cerebral metabolic } \\
\left.\text { rate of } \mathrm{O}_{2}\right)\end{array}$ & $\begin{array}{l}\text { Reduced lactate and } \\
\text { increased cerebral metabolic } \\
\text { rate of } \mathrm{O}_{2} \text { across both groups }\end{array}$ & $\begin{array}{l}\text { Compared HBOT to } \\
\text { normobaric hyperoxia } \\
(\mathrm{NBH})\end{array}$ \\
\hline
\end{tabular}

\section{Intermediate Phase}

The brain is considered an "immune-privileged" organ due to the presence of the selective blood-brain barrier (BBB) that impedes the entry of many foreign pathogens and immune mediators. However, TBI compromises this blockade and allows entry of chemical messengers and immune cells into the brain parenchyma; furthermore, TBI impacts central cytokine release within the brain itself. There are numerous postulated triggers of post-TBI inflammation, including: peripheral blood products, tissue and cellular debris, complement fragments, prostaglandins, and reactive oxygen and nitrogen species (RNS) [69]. Inflammation produces two disparate effects on brain tissue, on one end causing damage and the other promoting regeneration. For instance, activation of microglia promotes recovery via phagocytosis of debris; however, excessive cytokine and chemokine secretion prolong the inflammatory process. The inciting event to the inflammatory progression is the mechanical damage brought on by neurotrauma, causing the release of the aforementioned triggers and evoking a series of cellular events culminating in inflammation. A main measurable pathological sequela of neuroinflammation is elevated ICP which many of the treatment modalities to be discussed target. 
After the initiating injury, up-regulation of central nervous system (CNS) chemokines does not occur immediately. For instance CCL20, a lymphocyte chemotactic, increased centrally $48 \mathrm{~h}$ post-injury in a lateral FPI rat model of TBI. Interestingly, expression of CCL20 was increased in the periphery $24 \mathrm{~h}$ post-injury, suggesting a peripheral response prior to a central response [70]. Microglia, astrocytes, and neurons are all capable of producing additional chemokines in response to local inflammation [71]. The varying cell types have different responses to chemokines. The chemokine inflammatory proteins CCL3 and CXCL2 increase in mice post trauma, yet the MIP-2 receptor, CXCR2, increased expression only on astrocytes [72]. This data suggests targeted activity towards certain types of glia. Secreted chemokines encourage the expression of adhesion molecules on blood vessels which allows leukocyte extravasation from the periphery into the brain parenchyma. Leukocyte and lymphocyte entry into the CNS continues the inflammatory progression, though. However, such an infiltrate is time dependent because extravasation occurs slowly; neutrophil levels peak approximately two days post-TBI and monocytes slightly later [73]. Yet, a blast wave-induced TBI rat model found polymorphonuclear (PMN) leukocytes and lymphocytes in brain parenchyma within one hour of injury [74]. Regardless, neutrophils are the primary leukocytic infiltrate in the plasma of TBI patients acutely after injury [75]. Leukocyte homogenates from post-TBI patients display up-regulation of inducible-nitric oxide synthase (iNOS), cyclooxygenase-2 (COX-2), and nicotinamide adenine dinucleotide phosphate-oxidase (NADPH oxidase); all enzymes involved in producing the damaging neutrophilic oxidative burst and. Indeed, flow cytometry has confirmed increased oxidative activity in that leukocyte population [75].

Post-TBI there is increased neutrophilic infiltration, astrocytosis, edema, and both pro- and anti-inflammatory cytokines. The major pro-inflammatory cytokines released are interleukin-1 $\beta$ (IL-1 $\beta$ ), interleukin-6 (IL-6), and tumor necrosis factor alpha (TNF $\alpha$ ). The anti-inflammatory cytokines are interleukin-10 (IL-10) and transforming growth factor beta (TGF $\beta$ ) [76]. Other significant cytokines and chemokines involved in the pathophysiology of TBI have been reviewed elsewhere by Ziebell and Morganti-Kossman (2010) [77]. IL-1 $\beta$ and TNF are found present one hour post-injury, remain elevated for three weeks, and are accompanied by astrocytosis [74]. IL-1 $\beta$ is an especially potent pro-inflammatory cytokine capable of driving most of the inflammatory processes seen post-TBI. IL-1 $\beta$ is secreted by immune cell mediators and its processing is promoted by production of the NLRP3 inflammasome post-TBI [78]. Frugier et al. (2010) found IL-1 $\beta$ mRNA and that of IL-6, IL-8, and to be elevated in situ in post-mortem human brains after acute cerebral injury; interestingly, anti-inflammatory cytokine protein levels were unchanged [79]. IL-1 $\beta$ spurs a positive feedback mechanism leading to activation of microglia and further pro-inflammatory cytokine release. Microglia stimulated with IL-1 $\beta$ are activated and express the Krüppel-like factor 4 (K1f4) via a $\mathrm{PI} 3 \mathrm{~K} /$ Akt pathway leading to further production of IL-1 $\beta$. Additionally, there is increased COX-2, monocyte chemoattractant protein-1, and IL-6, as well as decreased expression of iNOS [80]. Importantly, IL-1 $\beta$ acts uniquely on astrocytes. When astrocytes are damaged as occurs in TBI, IL- $1 \beta$ activates the intracellular ERK pathway which releases matrix metalloproteinase-9 (MMP-9) from astrocytes in vitro [81]. MMPs degrades extracellular matrix and further promotes BBB breakdown promoting and prolonging neuroinflammation. The levels of MMP-9 and MMP-8 correlate with interleukin and TNF $\alpha$ levels in microdialysate and CSF of patients after severe TBI [82]. 
Secretion of TNF $\alpha$ by astrocytes and microglia occurs rapidly after TBI, with mRNA and protein levels detectable within $17 \mathrm{~min}$ of injury as measured in post-mortem brains of patients who died shortly after TBI [79]. TNF $\alpha$ action in the chronic neuroinflammation setting produces spatial learning and memory deficits, yet treatment with a TNFa protein synthesis inhibitor, 3,6'-dithiothalidomide (DT), actually spares these cognitive effects [83]. Interestingly, DT treatment spares IL-1 $\beta$ levels and still rescues behavioral function, suggesting TNF $\alpha$ plays a larger role in cognitive dysfunction. The detrimental effects of TNF $\alpha$ have been validated in clinical studies also. A cohort of 1096 TBI patients was analyzed for the effect of cytokine gene polymorphisms on Glasgow outcome scores. Homozygous carriers of the TNF $\alpha-308$ single nucleotide polymorphisms (SNP) had significantly worse outcomes after TBI; the SNP is present in the TNF $\alpha$ promoter and is linked to elevated TNF $\alpha$ levels $[84,85]$. In mice TNF $\alpha$ signaling via TNFR1 is positively linked to the expression of a myriad of gene products including aquaporin-4 (AQP4), a water channel which influences edema formation and is predominantly expressed in astrocytes; yet, this up-regulatory effect is not seen in cultured astrocytes [86,87].

Edematous changes during the inflammatory phase of TBI are tightly linked to regulation of water and ionic flow between the extracellular fluid and glia. As mentioned, AQP4 is a mediator of water homeostasis and appears to be the predominant AQP responsible for edema formation post-TBI [88]. AQP4 is upregulated in rat cortex as soon as 3 and $48 \mathrm{~h}$ post-injury in a blast-induced moderate neurotrauma experimental model; the same study also saw TNF $\alpha, \mathrm{C} 3 / \mathrm{C} 5 \mathrm{~b}-9$, and leukocyte infiltration all increase at those time points [89]. Indeed, AQP4 is also elevated in the CSF of severe TBI patients compared to healthy controls [90]. Brain edema which results from AQP4 over-expression is associated with increased fluorojade immunostains (marker of degenerating neurons) and neurobehavioral deficits [91]. Nevertheless, AQP4 also has advantageous effects in TBI pathophysiology. AQP4 has been shown to promote astrocytic scar formation and reduce post-TBI seizure severity; further establishing that inflammation during TBI has detrimental and beneficial effects [92]. Evidence also suggests the edematous response post-TBI is age dependent. Two month old and 21 month old rats subjected to CCI displayed similar morphological damage, yet the older rats had increased edema and more rapid onset of poor neurological outcome compared to those younger [93]. Edema directly contributes to the previously mentioned hallmark of TBI, raised intracranial pressure (ICP). Raised ICP in pediatric TBI patients produces long term detrimental abnormalities in cerebral architecture. Tasker et al. (2010) followed these pediatric patients for 4.9 years post-TBI and revealed decreased cross-sectional area, increased compaction, and thinning of the corpus callosum in addition to reduced fractional anisotropy [94].

As has been detailed, a number of cytokines, chemokines, and protein molecules enhance the inflammatory response post-TBI. Lloyd et al. (2008) attempted to reduce not one but many of these inflammatory mediators to understand their collective efforts. Mice treated with Minozac, an experimental therapeutic, after $\mathrm{CCI}$ had attenuated pro-inflammatory cytokines, less astrocyte activation, and no increase in brain edema [95]. This experimental data suggests global dampening of the inflammatory process improves outcomes. Minozac is but one pharmacological treatment studied in experimental models of TBI, numerous others have been reviewed elsewhere [96]. It then logically follows that quantifying the state of inflammation post-TBI would be therapeutically beneficial. Biomarkers of inflammation may serve as a quantitative figure to assess TBI severity. S100 calcium 
binding protein $\mathrm{B}(\mathrm{S} 100 \mathrm{~B})$ is secreted by astrocytes into the CSF upon injury and displays a strong correlation with injury severity as measured in head trauma patients. S100B, however, does not readily cross the BBB and also increases in response to peripheral trauma, making its use less feasible [97]. Hernanadez-Ontiveros et al. (2013) suggest the use of activated microglia as a TBI marker and useful criteria to influence therapeutic interventions; as is made explicit this task relies on decoding the unique cytokine and chemokine profile for such microglia after TBI [98]. Understanding the inflammatory cascade and its variability within different forms of TBI will be paramount in effectively treating subsets of injury.

\section{Progesterone, Hyperosmolar Agents, Decompressive Craniectomy (DC)}

There are no true guidelines for the treatment of the neuroinflammatory phase of TBI, but rather monitoring technologies and secondary prevention tactics aimed at ameliorating its sequelae, namely elevated ICP. ICP monitoring is recommended as level II evidence when GCS falls between 3 and 8 and is accompanied by an abnormal CT scan [99]. One strong contraindication for use in reducing ICP is corticosteroid administration, namely methylprednisolone. The widely acclaimed CRASH trial found elevated risk of death in patients administered methylprednisolone after brain injury [100]. Current research has explored other options including pharmacotherapies and surgical options, both of which will be discussed in light of ICP.

Progesterone, an endogenous steroid hormone, is a pharmacotherapy option gaining recent attention. Attella et al. (1987), somewhat serendipitously, first revealed the neuroprotective effects of progesterone. His experiments demonstrated reduced edema in pseudopregnant rats after frontal cortex lesions when compared to normal cycling rats [101]. Progesterone acts on the membrane bound progesterone receptor $(\mathrm{mPR} \alpha)$ which is expressed in neurons but not glia in the mouse brain. Strikingly, upon induction of TBI, $\mathrm{mPR} \alpha$ increases expression on oligodendrocytes, astrocytes, and reactive microglia, implying a role of progesterone in neuroprotection [102]. Since the early experiments others have explored progesterone's neuroprotective effect. For instance, Wright et al. (2001) found TBI-rodents administered progesterone had significantly reduced cerebral edema compared to controls [103]. Progesterone may reduce cerebral edema via elevation of $P$-glycoprotein expression, a marker tightly linked to BBB function [104]. In addition, progesterone modulates AQP4 expression spatially and temporally after TBI, affecting edema formation [105]. Trauma often leads to vascular injuries as well, and, appropriately, progesterone has been found to increase circulating endothelial progenitor cells post-TBI, suggesting a role in vascular remodeling [106]. The deleterious pro-inflammatory cytokines IL-6 and TNF $\alpha$, pro-apoptotic caspase-3 and bax, and the marker of lipid peroxidation 8-isoPGF2 have all been proven to be reduced by progesterone in rodent models of TBI [104,107-112]. Such cytokines and stressors lead to cell death in susceptible regions of the brain, notably the DG of the hippocampus. Yet, progesterone also reduces cell death in the DG of rats post-TBI [113]. Of note, progesterone administered with vitamin D after TBI reduces astrocyte proliferation and neuronal loss with a trend toward improved memory outcomes post-TBI when compared to rats supplemented with progesterone alone [114].

Besides experimental data, progesterone has garnered attention in clinical trials. The ProTECT RCT was one of the first to examine progesterone's efficacy post-TBI, reporting no serious adverse events 
and a lowered thirty day mortality rate compared to placebo [115]. A more recent study found five days of progesterone administration to TBI patients with a GCS less than or equal to 8 led to marked improvement at three month follow-up compared to placebo patients [116]. A pooled meta-analysis of small progesterone RCTs revealed progesterone reduces risk of mortality $(R R=0.61)$ and had a lower risk of death or severe disability $(\mathrm{RR}=0.77)$ [117]. As alluded to earlier, rodent studies have suggested vitamin $\mathrm{D}$ together with progesterone has synergistic benefits. In agreement, patients administered intramuscular progesterone followed by vitamin D within $8 \mathrm{~h}$ of TBI had elevated recovery rates, GOS outcomes, and reduced mortality [118]. More positive studies are needed to fully warrant the use of progesterone. The large scale SyNAPSe trial is one such RCT currently underway. The RCT hopes to determine if IV progesterone given with $8 \mathrm{~h}$ of TBI for a total of $120 \mathrm{~h}$ enhances patient recovery compared to placebo administered patients (Table 3).

Table 3. Progesterone Administration Evidence in TBI. Table 3 summarizes presented evidence regarding the effect of progesterone administration on TBI outcomes, including GOS and mortality. Most of evidence presented favors the use of progesterone based on multiple different outcomes. $*=$ Study as cited in text.

\begin{tabular}{|c|c|c|c|c|}
\hline Study & Design & $\begin{array}{l}\text { Primary } \\
\text { Outcome }\end{array}$ & Results & Notes \\
\hline $\begin{array}{l}\text { Wright et al. } \\
2007 *[115]\end{array}$ & $\begin{array}{l}\text { Phase II RCT } \\
\text { with placebo }\end{array}$ & $\begin{array}{l}\text { GOS-extended } \\
\text { adverse events } \\
30 \text { day } \\
\text { mortality }\end{array}$ & $\begin{array}{l}\text { Progesterone and placebo group } \\
\text { had similar adverse event rates. } \\
\text { Progesterone had lower } 30 \text { day } \\
\text { mortality. Moderate TBI patients } \\
\text { receiving progesterone more } \\
\text { likely to have } \\
\text { improved outcome }\end{array}$ & $\begin{array}{l}\text { Three days progesterone } \\
\text { treatment } 30 \text { day mortality } \\
\text { Rate ratio }(\mathrm{RR}) \text { in } \\
\text { progesterone group }=0.43 \\
95 \% \mathrm{CI}=0.18-0.99 \\
\text { GOS-E in severe TBI } \\
\text { patients; RR }=0.79 ; \\
95 \% \mathrm{CI}=0.29-2.13\end{array}$ \\
\hline $\begin{array}{l}\text { Shakeri et al. } \\
2013 *[116]\end{array}$ & $\begin{array}{l}\text { Prospective } \\
\text { randomized } \\
\text { trial }\end{array}$ & GOS & $\begin{array}{l}\text { Significantly improved GOS and } \\
\text { recovery in progesterone group } \\
(50 \%) \text { compared to control } \\
(21 \%) \text { at } 3 \text { months }\end{array}$ & $\begin{array}{l}1 \mathrm{mg} / \mathrm{kg} \text { progesterone every } \\
12 \mathrm{~h} \text { for } 5 \text { days; Patients with } \\
\mathrm{GCS} \leq 8 \text { enrolled }\end{array}$ \\
\hline $\begin{array}{l}\text { Ma et al. } \\
2012 *[117]\end{array}$ & Meta-analysis & Mortality & $\begin{array}{l}\text { Progesterone reduced mortality } \\
\text { at end of follow-up } \\
\text { and disability }\end{array}$ & $\begin{array}{l}\text { Mortality with progesterone } \\
\text { pooled risk ratio }=0.61, \\
95 \% \mathrm{CI}=0.40-0.93 \\
\text { Death and severe disability } \\
\text { with progesterone pooled risk } \\
\text { ratio }=0.77, \\
95 \% \mathrm{CI}=0.62-0.96\end{array}$ \\
\hline $\begin{array}{l}\text { Aminmansour } \\
\text { et al. } 2012 * \\
{[118]}\end{array}$ & $\begin{array}{l}\text { RCT with } \\
\text { placebo }\end{array}$ & GOS & $\begin{array}{l}\text { Favorable Outcomes at } \\
3 \text { months Placebo }=25 \% \\
\text { Progesterone }=45 \% \\
\text { Progesterone }+ \text { Vitamin } \mathrm{D}=60 \% \\
p=0.03\end{array}$ & $\begin{array}{l}\text { Separate group receiving } \\
\text { progesterone and } \\
\text { vitamin D included }\end{array}$ \\
\hline
\end{tabular}

Neuroinflammation promotes edema formation and expansion within the spatially limited cranial cavity, thus increasing ICP. Prolonged ICP elevation can be the stem from which many pathogenic 
features of TBI arise. The BTF currently recommends, as level II evidence, the use of mannitol for the control of raised ICP after TBI while maintaining systolic blood pressure above $90 \mathrm{mmHg}$ [119]. By controlling ICP, mannitol allows diagnostic and interventional procedures, such as CT scan and intracranial evacuation, to be completed more easily. Mannitol's effectiveness may stem from promotion of vasoconstriction, thus lowering ICP [120].

Hypertonic saline (HS) solutions are other hyperosmolar agents which have been the target of ongoing research because of fewer effects on blood pressure compared to mannitol. Both treatments reduce ICP yet a recent meta-analysis found a trend favoring hypertonic sodium solutions because of greater ICP reduction [121]. One such solution is sodium lactate which has been independently found to outperform mannitol in terms of reducing ICP $(7 \mathrm{mmHg}$ drop vs. $4 \mathrm{mmHG})$ and acting longer; sodium lactate has also been successful at more dilute (half molar) concentrations [122]. HS is also useful in cases of elevated ICP which do not respond to other therapies. For instance, repeated administration of $14.6 \%$ HS in a cohort of patients with elevated ICP completely refractory to other therapies was shown successful in reducing ICP [123]. Other studies have confirmed this finding by directly comparing mannitol and HS in similar refractory cases of elevated ICP. One such study also revealed HS to significantly elevate brain oxygenation compared to mannitol [124]. By reducing ICP, hyperosmolar agents may elevate cerebral perfusion pressure (CPP) which is beneficial when focal regions are hypoperfused from trauma; mannitol and HS both have demonstrated this effect in an eight-patient, acute TBI cohort [125]. Yet, when compared with mannitol directly in a randomized trial, HS increased cerebral blood flow (CBF) and CPP more and for an increased duration [126]. Although the data for HS is appealing the BTF does not have enough evidence to support HS over mannitol at this point in time (Table 4).

A slightly more controversial procedure used in managing raised ICP is decompressive craniectomy (DC) where a skull flap is removed to allow space for the swelling brain. Early trials revealed positive outcomes in greater than $50 \%$ of patients with severe TBI based on GOS-E [127]. However, the procedure maintains a high mortality rate of $26.4 \%$ post-operation with the rate being higher with increased age and lower GCS score [128]. Interestingly, when DC is paired with mass evacuation, mortality rate actually decreases compared to DC without mass evacuation in TBI patients [129]. In addition to mortality rate, $\mathrm{DC}$ is associated with numerous adverse outcomes, including: contusion expansion, new contralateral subdural or epidural hematoma, CSF leakage, epilepsy, cerebral herniation, subdural effusion, and infection. In agreement with previous studies, adverse outcomes were more common when GCS score was below 8 and age above 65 [130]. Still, blast-induced TBI occurring in the combat arena is one context where DC is aggressively used, partially because of the younger age and health status of military members [131]. Regardless of potential adverse effects, DC does successfully control ICP and CBF in TBI patients [132,133]. On the other hand, DC is associated with reduced cerebral metabolic rate of oxygen, which is a value positively correlated with functional outcomes [132]. The DECRA trial was one large scale RCT which examined the usefulness of DC after diffuse TBI. In that trial DC was effective in rapidly reducing ICP and time in the intensive care unit however it led to worse outcomes; $70 \%$ had an unfavorable outcome in the DC group compared to $51 \%$ in the standard care group [134]. The conversation regarding the DECRA trial has been ongoing due to problematic study design, causing some to dismiss its clinical influence. Honeybul et al. (2013) point out that patients randomized to the surgery arm of the trial may have had 
more severe injuries and that substantial crossover from the standard care group to the surgery group skewed the results [135]. Of note, when DC is performed up to a week after TBI there are still comparable GOS outcomes as compared to those having the procedure done within a day after injury and those receiving a standard, conservative treatment [136]. One intriguing aspect of DC is that it is very cost-effective compared to comfort care at a range of patient ages [137]. However, this cost-effectiveness wanes as the severity of TBI increases [138]. The overall picture regarding DC's use post-TBI is summed up nicely by Lemcke et al. (2010), who posits that the prognosis post-operation is generally poor but predictive indicators of outcome should be taken into consideration, including age, midline shift, and quality of the basal cisterns on head CT [139].

Table 4. Hyperosmolar Agents Evidence in TBI. Table 4 summarizes selected evidence regarding hyperosmolar agents in TBI. The evidence compares the use of hypertonic saline (HS) and mannitol in reducing ICP during neuroinflammation. Mannitol is the gold standard hyperosmolar agent recommended for use by the BTF. However, the evidence provides strong support in favor of HS. * = Study as cited in text.

\begin{tabular}{|c|c|c|c|c|}
\hline Study & Design & Primary Outcome & Results & Notes \\
\hline $\begin{array}{l}\text { Rickard et al. } \\
2013 *[121]\end{array}$ & Meta-analysis & $\begin{array}{l}\text { Pooled mean ICP } \\
\text { reduction }\end{array}$ & $\begin{array}{l}\text { Weighted mean ICP reduction } \\
\text { difference with hypertonic saline } \\
\text { compared mannitol }=1.39 \mathrm{mmHg} \text {, } \\
95 \% \mathrm{CI}=-0.74-3.53\end{array}$ & $\begin{array}{l}\text { Six studies with } \\
171 \text { patients and } \\
599 \text { episodes } \\
\text { of raised } \\
\text { ICP included }\end{array}$ \\
\hline $\begin{array}{l}\text { Ichai et al. } \\
2013 *[122]\end{array}$ & $\begin{array}{l}\text { RCT receving } \\
\text { either half-molar } \\
\text { sodium lactate } \\
\text { (SL) or } \\
\text { isotonic saline }\end{array}$ & $\begin{array}{l}\text { Raised ICP episodes } \\
(\geq 20 \mathrm{mmHg})\end{array}$ & $\begin{array}{l}\text { Half-molar SL group had } \\
\text { significantly fewer raised ICP } \\
\text { episodes compared to control } \\
(p<0.05)\end{array}$ & $\begin{array}{l}\text { Patients received } \\
48 \mathrm{~h} \text { continuous } \\
\text { infusion } \\
(0.5 \mathrm{~mL} / \mathrm{kg} / \mathrm{h})\end{array}$ \\
\hline $\begin{array}{l}\text { Eskandari et } \\
\text { al. } 2013 * \\
{[123]}\end{array}$ & $\begin{array}{l}\text { Prospective } \\
\text { cohort study }\end{array}$ & $\begin{array}{l}\text { Refractory } \\
\text { intracranial } \\
\text { hypertension } \\
\text { treatment response }\end{array}$ & $\begin{array}{l}\text { Boluses significantly decreased } \\
\text { ICP and sustained the decrease and } \\
\text { elevated CPP }\end{array}$ & $\begin{array}{l}\text { Using } 14.6 \% \\
\text { Hypertonic Saline } \\
\text { Boluses repeated } \\
\text { every } 15 \mathrm{~min} . \\
\text { over } 12 \mathrm{~h}\end{array}$ \\
\hline $\begin{array}{l}\text { Oddo et al. } \\
2009 *[124]\end{array}$ & $\begin{array}{l}\text { Prospective } \\
\text { study }\end{array}$ & $\begin{array}{l}\text { Elevated ICP } \\
\text { refractory to } \\
\text { mannitol-Response } \\
\text { to hypertonic saline } \\
\text { (HS) }\end{array}$ & $\begin{array}{l}\text { HS significantly elevated brain } \\
\text { tissue oxygenation, reduced ICP, } \\
\text { and elevated cardiac output } \\
\text { compared to mannitol }\end{array}$ & $\begin{array}{l}7.5 \%, 250 \mathrm{~mL} \\
\text { HS treatment }\end{array}$ \\
\hline $\begin{array}{l}\text { Cottenceau et } \\
\text { al. } 2011 * \\
{[125]}\end{array}$ & $\begin{array}{l}\text { Randomized } \\
\text { prospective } \\
\text { study }\end{array}$ & $\begin{array}{l}\text { ICP, CPP, CBF, } \\
\text { outcome }\end{array}$ & $\begin{array}{l}\text { Mannitol and HS both reduced } \\
\text { ICP and elevated CPP and CBF. } \\
\text { HS had significantly more } \\
\text { pronounced effect over greater } \\
\text { duration. No difference in outcome } \\
\text { between two groups }\end{array}$ & $\begin{array}{l}20 \% \text { Mannitol } \\
(4 \mathrm{~mL} / \mathrm{kg}) \\
7.5 \% \mathrm{HTS} \\
(2 \mathrm{~mL} / \mathrm{kg})\end{array}$ \\
\hline
\end{tabular}




\section{Late Phase}

Seizures are among the more prominent long-term sequelae of TBI, progressing into epilepsy in more severe cases. The initial cellular trauma brought on by TBI promotes cell death and inflammation. Intriguingly, greater and prolonged BBB disruption is seen in patients who develop post-traumatic epilepsy (PTE) compared to those who do not develop epilepsy after TBI, suggesting inflammation and infiltration play a role in epileptogenesis [140]. Nonetheless, the ultimate purpose of inflammation is to clear the damage and debris so repair may ensue. Self-repair processes modify neuronal circuitry and may lead to an epileptogenic transformation in focal or diffuse areas [141]. Seizures post-TBI are generally classified based on onset time: immediate ( $<24 \mathrm{~h}$ post-injury), early ( $<1$ week post-injury), and late $(>1$ week post-injury). Early and late seizures will primarily be discussed here as they are more often due to altered neural circuitry rather than direct, immediate sequelae of injury.

In a simple sense, seizures develop when excitatory potentials become favored over inhibitory potentials and this affects the synchronous entrainment of multiple neurons. The hippocampus and cortex are especially prone to epileptiform activity. In the hippocampus of rats, TBI reduces Kv.4.2 (A-type $\mathrm{K}^{+}$Channel) expression and current flow, causing neurons to become more excitable and more prone to bicuculline-induced seizures [142]. Hippocampal mossy fibers connecting granule cells of the dentate gyrus (DG) with CA3 are re-organized post-TBI, possibly involving activation of the trkB-ERK1/2-CREB/Elk-1 signaling path [143]. Data suggest trkB expression is coincident with GAP43 expression, a marker of axonal growth; extension of neuron processes alters neural circuitry and mossy fiber sprouting (MFS) is one such change [144]. MFS seems necessary for epileptiform activity. For example, brain slices from CCI mice have abnormal electrical activity, including elevated excitatory post-synaptic currents (EPSC), but those injured without MFS do not significantly differ from controls $[145,146]$. MFS is a consistent pathological hallmark, and is seen in the ipsilateral DG of $95 \%$ of mice $8-12$ weeks after suffering a brain injury (however, sprouting may be present earlier) [146]. Such sprouting depends on the severity of TBI and whether the cortex impinges on the hippocampus [147]; for instance, $20 \%$ of mild-CCI mice displayed spontaneous seizures whereas $36 \%$ of severe-CCI mice suffered the same affliction [145]. Molecular analysis of the hippocampi of epileptic patients who suffered trauma demonstrates MFS in addition to focal cell loss in the hilar region of the DG. The patients studied had MFS which was present from 4-18 years post-injury; such data grounds MFS as clinically relevant [148]. In our lab, using a CCI mouse model, we demonstrated administration of imipramine, a tricyclic antidepressant, to stimulate hippocampal neurogenesis. Of note, most bromodeoxyuridine (BrdU)-positive progenitors became neurons in the DG and astrocytes in the hilus [149]. Since the hippocampus is particularly susceptible to damage, the stimulation of neurogenesis and reduction in cell death may be a means by which to reduce seizure activity. Our lab identified Nogo-66 receptor 1 (NgR1) to inhibit recovery post-CCI in mice; mice lacking $\mathrm{NgR} 1$ displayed improved performance on the Novel Object Recognition test and increases in markers of cell proliferation and recovery compared to control CCI mice [150].

Reduction of inhibitory currents is another means by which TBI promotes seizure activity. The hippocampus relies on inhibitory GABA currents for proper function and disruption leads to abnormal electrical activity. For instance, one month after FPI, rats display reductions in $\mathrm{GABA}_{\mathrm{A}}$ currents in 
ipsilateral DG granule cells, eventually progressing to the hippocampus contralateral to injury by six months [151]. Also, bathing $\mathrm{GABA}_{\mathrm{A}}$ antagonists on hippocampal slices from experimental TBI rats elicits the abnormal hyperexcitability in the granule and molecular cell layers [152]. In particular, GABAergic hippocampal interneurons of the parvalbumin, calretinin, or neuropeptide $\mathrm{Y}$ immunoreactive classes are affected by TBI [153]. The DG and CA3 regions are also primarily vulnerable as seen in an intricate stereological FPI rat model that induced interneuron death in the DG and CA3 with resultant increased excitability in the DG. Interestingly, however, the CA displayed reduced excitability in that study [154].

Overall, synaptic alterations in inhibitory and excitatory circuits of the hippocampus play a role in seizures post-TBI. Notably, the hippocampus may be a key biomarker in identifying susceptibility to epileptic activity. PET and MRI have been used to identify functional and structural changes post-TBI which may account for epileptic outcomes. Most areas studied could not foretell outcome, however ipsilateral hippocampus surface shapemeasured with PET and analyzed using multivariate logistic regression could predict epileptic outcomes in rats [155]. Similar results extend into the clinical realm where volumetric MRI of TBI patients demonstrated greater hippocampal atrophy in those with seizures [156]. Besides the hippocampus, the cortex is also particularly prone to epileptiform activity. One week post-injury, pyramidal cells in layer V of the neocortex of CCI-rats displayed evoked abnormal discharges followed by repetitive post-discharge; by two weeks the evoked activity progresses and spontaneous discharges also occur [157]. Similar mechanisms of epileptogenesis exist in the cortex and hippocampus yet pharmacological therapies do not make a distinction upon where they preferentially act.

\section{Seizure Treatments}

Seizures are common post-TBI occurring in approximately $50 \%$ of patients 15 years after a penetrating injury. Post-traumatic seizures may be classified as early $(<1$ week post-injury) or late ( $>1$ week post-injury), with an incidence of $4 \%-25 \%$ and $9 \%-42 \%$, respectively, in untreated patients [158-160]. There are numerous factors which put patients at increased risk for post-traumatic seizures, including: GCS $<10$, cortical contusion, depressed skull fracture, subdural or epidural hematoma, intracerebral hematoma, penetrating head wounds, and seizures within $24 \mathrm{~h}$ of injury [161,162]. According to the Brain Trauma Foundation's (BTF) management guidelines there are no level I recommendations for anti-seizure prophylaxis. Rather, there are level II recommendations which suggest using anticonvulsants such as phenytoin and valproate to prevent early seizures but not late seizures because of the side-effects associated with chronic use [163]. Other anti-convulsants such as phenobarbital and carbamazepine are generally avoided because of adverse effects and pharmacodynamic profile [164]. Besides acute therapy, there is a relative paucity in pharmacological options for seizure prophylaxis post-TBI; yet, promising agents have shown success in preliminary trials.

Levetiracetam (LEV) is an anticonvulsant which binds synaptic vesicle glycoprotein 2A (SV2A) and likely inhibits presynaptic $\mathrm{Ca}^{2+}$ channels $[165,166]$. In basic science work, intraperitoneal LEV given daily to rats which suffered CCI led to improved motor function, reduced hippocampal cell loss, decreased contusion volumes, and reduced IL-1 $\beta$ expression [167]. Clinically, a recent phase II trial 
among 20 paediatric cases of TBI showcased LEV as a feasible option to prevent seizures in high-risk patients because of its safety and lack of adverse events [168]. Additional studies would have to compare LEV to phenytoin (PHT), the current acute prophylactic standard. One comparison was a meta-analysis revealing equal efficacy between PHT and LEV; the authors suggested further high quality RCTs be completed before conclusions are drawn [169]. Addition of electroencephalography (EEG) to trials comparing outcome after PHT or LEV administration demonstrated that epileptiform activity and discharges were not predictive of outcome in either group [170]. Kruer et al. (2013) completed a retrospective observational study comparing PHT and LEV. Of 109 patients studied (89 receiving PHT and 20 with LEV), only one patient in each group suffered a post-traumatic seizure with a trend favoring LEV [171]. Interestingly, anticonvulsant therapy was continued past seven days in that study, against the present guidelines. IV administration of LEV and PHT in a prospective, randomized trial showed LEV to improve long-term outcomes based on Disability Rating Score and GOS but have no effect on seizure occurrence compared to PHT [172]. Other prospective multicenter comparisons of PHT and LEV for prophylaxis of acute seizures found no significant improvement in outcomes when LEV was administered [173]. Most studies have examined LEV vs. PHT in treating early but not late seizures. Recently a Phase III trial wishing to examine LEV's ability to reduce both early seizures and late epilepsy was terminated due to small enrolment, leaving such a question yet to be answered.

The literature is in disagreement concerning the efficacy of LEV as a first-line treatment. Yet, LEV is still appealing because it does not require serum monitoring, which PHT demands owing to its non-linear metabolism. However, Pieracci et al. (2012) make the argument PHT is more cost-effective than LEV to both the institution and patient, ultimately recommending PHT remain the first-line therapy [174]. Cotton et al. (2011) quantified costs of a seven-day course of PHT and LEV, revealing the values to be 37.50 USD and 480.00 USD, respectively [175]. Still, significant disagreement regarding cost-effectiveness exists. Kazerooni et al. (2010) reported LEV as having the potential to be a more fiscally conservative option; based on experimental data they calculated the incremental cost-effectiveness ratio of LEV/PHT for each successful seizure prophylaxis regimen to be 360.82 USD [176]. Regardless of monetary incentive, accounting for valuable clinical time saved in forgoing serum monitoring of patients may be enough to give LEV an advantage over PHT.

As mentioned earlier, barbiturates, such as phenobarbital, are avoided as a first line therapy due to adverse effects [164]. Trials in Europe examining the effects of barbiturates on treatment were completed to no avail. While high dose barbiturates successfully decrease the elevated ICP typical of TBI they also lead to extended hemodynamic instability even when vasopressive agents are administered [177]. Valproate has been studied for early seizures with results demonstrating a trend toward favorable outcomes but the study failed to achieve significance and was not adequately powerful to detect a change [178]. Excitingly though, a phase III study sponsored by the National Institute of Neurological Disorder and Stroke evaluating valproate against PHT for seizures post-TBI was recently completed but the results not yet released. Topiramate, yet another anticonvulsant, is currently being studied in the PEPTO trial to compare it to PHT in preventing epilepsy after TBI. Recent evidence demonstrates ethosuximide, another anti-convulsant, as capable of decreasing the incidence, frequency, and delaying the onset of non-convulsive seizures in rats 
suffering a penetrating ballistic-like brain injury [179]. However, ethosuximide treatment has not been attempted in the clinical arena (Table 5).

Table 5. Anti-Epileptic Drugs Evidence in TBI: Case for Levetiracetam. Table 5 displays selected evidence regarding the use of levetiracetam (LEV) in preventing seizures post-TBI, often as compared to phenytoin (PHT). PHT is the mainstay treatment for seizure prophylaxis as recommended by the BTF. Many studies display similar results on seizure prevention concerning LEV and PHT. However, LEV may be more clinically practical than PHT. $*$ = Study as cited in text.

\begin{tabular}{|c|c|c|c|c|}
\hline Study & Design & Primary Outcome & Results & Notes \\
\hline $\begin{array}{l}\text { Pearl et al. } 2013 \\
*[168]\end{array}$ & $\begin{array}{l}\text { Phase II } \\
\text { prospective trial }\end{array}$ & $\begin{array}{l}\text { Posttraumatic } \\
\text { epilepsy (PTE) } \\
\text { development } \\
\text { sdverse events } \\
\text { mortality }\end{array}$ & $\begin{array}{l}\text { 1/40 patients developed PTE. } \\
\text { Non-serious adverse events: } \\
\text { headache, fatigue, irritability, } \\
\text { drowsiness. No mortality at } \\
\text { follow-up }\end{array}$ & $\begin{array}{l}\text { Children 6-17 years } \\
\text { LEV } 55 \mathrm{mg} / \mathrm{kg} / \text { day } \\
\text { for } 30 \text { day. } 2 \text { year } \\
\text { follow-up }\end{array}$ \\
\hline $\begin{array}{l}\text { Zafar et al. } \\
2012 *[169]\end{array}$ & Meta-analysis & $\begin{array}{l}\text { seizures between } \\
\text { LEV and PHT }\end{array}$ & $\begin{array}{l}\text { Neither drug was superior to } \\
\text { the other in reducing seizures }\end{array}$ & $\begin{array}{l}\text { Pooled OR }=0.96 \\
95 \% \mathrm{CI}=0.24-3.79\end{array}$ \\
\hline $\begin{array}{l}\text { Kruer et al. } \\
2013 *[171]\end{array}$ & $\begin{array}{l}\text { retrospective } \\
\text { observational } \\
\text { study }\end{array}$ & $\begin{array}{l}\text { posttraumatic } \\
\text { seizures }\end{array}$ & $\begin{array}{l}89 \text { received PHT, } 20 \text { received } \\
\text { LEV. } 1 \text { patient suffered a } \\
\text { seizure in each group }\end{array}$ & $\begin{array}{l}\text { Most patients had } \\
\text { AED prophylaxis for } \\
>7 \text { days despite } \\
\text { guidelines }\end{array}$ \\
\hline $\begin{array}{l}\text { Szaflarski et al. } \\
2010 *[172]\end{array}$ & $\begin{array}{l}\text { Prospective, } \\
\text { randomized, } \\
\text { single-blind trial } \\
\text { PHT vs. LEV }\end{array}$ & $\begin{array}{l}\text { GOS } \\
\text { disability rating } \\
\text { scale (DRS) } \\
\text { seizures mortality }\end{array}$ & $\begin{array}{l}\text { LEV had lower DRS } \\
(p=0.042) \text { and higher GOS } \\
(p=0.039) \text {. No significant } \\
\text { difference in seizure } \\
\text { occurrence or mortality. }\end{array}$ & $\begin{array}{l}\text { DRS completed at } \\
3 \text { months, GOS at } \\
6 \text { months. Continuous } \\
\text { EEG used to measure } \\
\text { seizure occurrence } \\
\text { over initial } 72 \mathrm{~h} \text {. }\end{array}$ \\
\hline $\begin{array}{l}\text { Inaba et al. } \\
2013 *[173]\end{array}$ & $\begin{array}{l}\text { Prospective } \\
\text { study } \\
\text { PHT vs. LEV }\end{array}$ & $\begin{array}{l}\text { Early } \\
\text { post-traumatic } \\
\text { seizures mortality }\end{array}$ & $\begin{array}{l}\text { No difference between LEV } \\
\text { and PHT in seizure rate } \\
(1.5 \% \text { vs. } 1.5 \%, p=0.997) \text { or } \\
\text { mortality }(5.4 \% \text { vs. } 3.7 \% \text {, } \\
p=0.236)\end{array}$ & $\begin{array}{l}\text { LEV: } 1,000 \mathrm{mg} \text { every } \\
12 \mathrm{~h} ; \text { PHT: loading } \\
\text { dose } 20 \mathrm{mg} / \mathrm{kg}, \\
\text { maintenance dose } \\
5 \mathrm{mg} / \mathrm{kg} / \mathrm{d} \text { rounded to } \\
\text { nearest } 100 \mathrm{mg} .\end{array}$ \\
\hline
\end{tabular}

A surgical option for treatment of post-traumatic epilepsy is implantation of a vagal nerve stimulator (VNS). Generally, a small stimulator is implanted in the chest wall in the vicinity of the vagus nerve; it is believed the stimulator acts by altering norepinephrine and elevating GABA levels [180]. VNS effects have been observed in rodent models of TBI but few clinical studies have been completed. Englot et al. (2012) retrospectively compared outcomes of VNS in patients with post-traumatic epilepsy (PTE) and those with non-traumatic epilepsy. The group found PTE patients to have larger reductions in seizure frequency and a greater clinical response compared to non-traumatic epileptics [181]. Current pilot studies by Dr. Samadani and colleagues to understand prospective clinical outcomes in patients who receive a VNS after TBI are underway and successful work would pave the way for larger trials [182]. 


\section{Conclusions}

The present review outlines the pathophysiological processes which occur post-TBI and treatments aimed at ameliorating them. The distinction between phases is dependent upon the processes rather than being separated in time. Penetrating injury, mechanical stress, acceleration-deceleration injury, and shear forces provide the direct trauma-induced damage. These forces deregulate CBF and cause direct cellular-injury which leads to excitotoxic neuronal death. The reduced CBF deregulates cerebral metabolism and depletes energy stores within the brain. Prophylactic hypothermia and HBOT are two treatments which aim to reduce the energy expenditure of the brain and provide increased $\mathrm{O}_{2}$, respectively. Both treatments aim at pushing cerebral metabolism toward its normal, aerobic state. Elsewhere, we provide a detailed review of the technology and areas of improvement regarding both prophylactic hypothermia and HBOT [183]. Following immediate cell death and debris accumulation resident immune cells release cytokines and chemokines promoting neuroinflammation. The immediate damage resulting from trauma also comprises the BBB and allows entry of circulating immune regulators which contribute further to neuroinflammation. Numerous trials have recognized progesterone's neuroprotective potential and ability to combat inflammatory processes. Inflammation is also characterized by cerebral edema which elevates ICP which may cause serious herniations. Hyperosmolar agents, such as mannitol and hypertonic saline, are currently used to reduce elevated ICP and are recommended by the Brain Trauma Foundation. A less supported treatment route is decompressive craniectomy where a skull flap is removed to allow space for cerebral expansion. However, high mortality and complication rates make this option less beneficial and more controversial fo take place and aim to salvage neuronal damage which is repairable. Central to these acts include synaptic reorganization which alters the neuronal circuitry. The hippocampus and cortex are two regions particularly susceptible to damage and faulty repair in these regions contributes to abnormal electrical activity, resulting in seizures and possibly epilepsy. The BTF recommends the use of phenytoin for one week post-injury to reduce the risk for seizures. Other antiepileptic options are emerging, such as levetiracetam, as well as implantation of vagal nerve stimulators. Regardless, further research is warranted for the long-term use of anti-epileptic medications post-TBI (Figure 1).

Undoubtedly, the heterogeneous pathology of TBI makes uniform treatment recommendations difficult. A number of the reviewed studies recruited patients that were similar, whether it was in age, severity of injury, or imaging characteristics; narrowing the TBI population into homogenous groups yields clinically practical recommendations. Understanding the context, type of injury, and predominating pathophysiological mechanisms in a case will surely assist in the treatment and management of the TBI patient.

Figure 1 displays a general schematic regarding the overall pathophysiology of TBI. After injury, reduced $\mathrm{CBF}$ occurs from mechanical damage and leads to excitotoxicity-mediated cell death. Cell death produces an inflammatory state brought on by resident microglia and immune cells recruited from the periphery, leading to an elevation in ICP and a reduction in CPP. Inflammation eventually serves to repair the damage caused by TBI and is allows synaptic reorganization to occur. Reorganization and lasting damage increases susceptibility to seizures and possibly epilepsy. Hypothermia and HBOT target the deregulated cerebral metabolism and oxygen levels immediately after injury. Hyperosmolar agents, progesterone, and decompressive craniectomy seek to reduce 
inflammation caused by TBI and the ensuing damage. AEDs, such as LEV and PHT, and vagal nerve stimulation (VNS) reduce the probability of post-traumatic seizures.

Figure 1. TBI pathologic process and treatment targets.

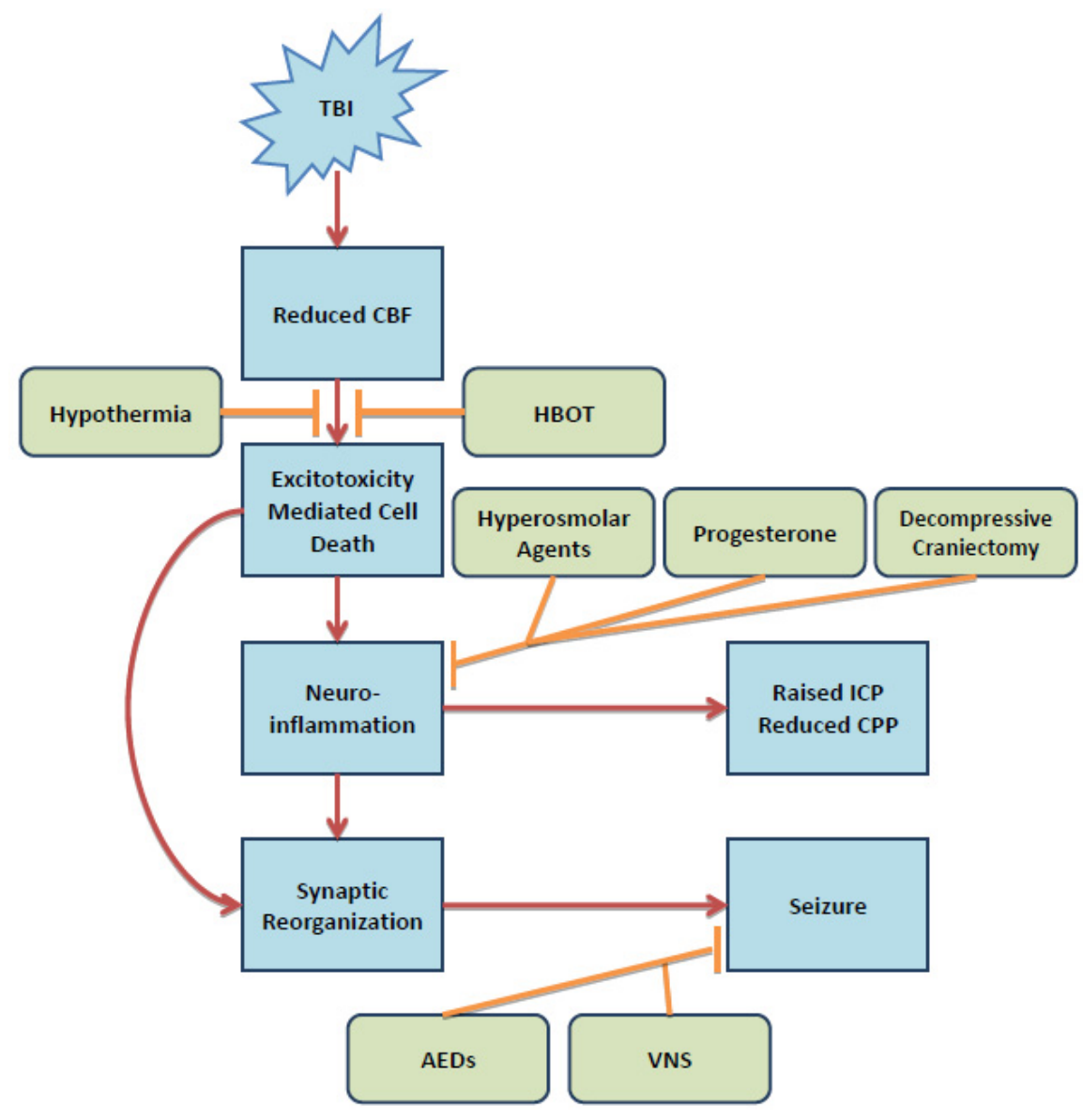

\section{Conflicts of Interest}

The authors declare no conflict of interest.

\section{References}

1. Faul, M.X.L.; Wald, M.M.; Coronado, V.G. Traumatic Brain Injury in the United States: Emergency Department Visits, Hospitalizations, and Deaths; Centers for Disease Control and Prevention, National Center for Injury Prevention and Control: Atlanta, GA, USA, 2010.

2. Lu, J.; Marmarou, A.; Choi, S.; Maas, A.; Murray, G.; Steyerberg, E.W. Mortality from traumatic brain injury. Acta Neurochir. Suppl. 2005, 95, 281-285.

3. Ghajar, J.; Hariri, R.J.; Narayan, R.K.; Iacono, L.A.; Firlik, K.; Patterson, R.H. Survey of critical care management of comatose, head-injured patients in the United States. Crit. Care Med. 1995, $23,560-567$.

4. Hesdorffer, D.C.; Ghajar, J.; Iacono, L. Predictors of compliance with the evidence-based guidelines for traumatic brain injury care: A survey of United States trauma centers. J. Trauma 2002, 52, 1202-1209. 
5. Leung, L.Y.; Wei, G.; Shear, D.A.; Tortella, F.C. The acute effects of hemorrhagic shock on cerebral blood flow, brain tissue oxygen tension, and spreading depolarization following penetrating ballistic-like brain injury. J. Neurotrauma 2013, 30, 1288-1298.

6. Hawkins, B.E.; Cowart, J.C.; Parsley, M.A.; Capra, B.A.; Eidson, K.A.; Hellmich, H.L.; Dewitt, D.S.; Prough, D.S. Effects of trauma, hemorrhage and resuscitation in aged rats. Brain Res. 2013, 1496, 28-35.

7. Kim, J.; Whyte, J.; Patel, S.; Europa, E.; Slattery, J.; Coslett, H.B.; Detre, J.A. A perfusion fMRI study of the neural correlates of sustained-attention and working-memory deficits in chronic traumatic brain injury. Neurorehabil. Neural Repair 2012, 26, 870-880.

8. Kaloostian, P.; Robertson, C.; Gopinath, S.P.; Stippler, M.; King, C.C.; Qualls, C.; Yonas, H.; Nemoto, E.M. Outcome prediction within twelve hours after severe traumatic brain injury by quantitative cerebral blood flow. J. Neurotrauma 2012, 29, 727-734.

9. Murakami, Y.; Wei, G.; Yang, X.; Lu, X.C.; Leung, L.Y.; Shear, D.A.; Tortella, F.C. Brain oxygen tension monitoring following penetrating ballistic-like brain injury in rats. J. Neurosci. Methods 2012, 203, 115-121.

10. Oddo, M.; Levine, J.M.; Kumar, M.; Iglesias, K.; Frangos, S.; Maloney-Wilensky, E.; Le Roux, P.D. Anemia and brain oxygen after severe traumatic brain injury. Intensive Care Med. 2012, 38, 1497-1504.

11. Bratton, S.L.; Chestnut, R.M.; Ghajar, J.; McConnell Hammond, F.F.; Harris, O.A.; Hartl, R.; Manley, G.T.; Nemecek, A.; Newell, D.W.; Rosenthal, G.; et al. Guidelines for the management of severe traumatic brain injury. IX. Cerebral perfusion thresholds. J. Neurotrauma 2007, 24, S59-S64.

12. Eriksson, E.A.; Barletta, J.F.; Figueroa, B.E.; Bonnell, B.W.; Vanderkolk, W.E.; McAllen, K.J.; Ott, M.M. Cerebral perfusion pressure and intracranial pressure are not surrogates for brain tissue oxygenation in traumatic brain injury. Clin. Neurophysiol. 2012, 123, 1255-1260.

13. Glenn, T.C.; Kelly, D.F.; Boscardin, W.J.; McArthur, D.L.; Vespa, P.; Oertel, M.; Hovda, D.A.; Bergsneider, M.; Hillered, L.; Martin, N.A. Energy dysfunction as a predictor of outcome after moderate or severe head injury: Indices of oxygen, glucose, and lactate metabolism. J. Cereb. Blood Flow Metab. 2003, 23, 1239-1250.

14. Cunningham, A.S.; Salvador, R.; Coles, J.P.; Chatfield, D.A.; Bradley, P.G.; Johnston, A.J.; Steiner, L.A.; Fryer, T.D.; Aigbirhio, F.I.; Smielewski, P.; et al. Physiological thresholds for irreversible tissue damage in contusional regions following traumatic brain injury. Brain 2005, 128, 1931-1942.

15. Stein, N.R.; McArthur, D.L.; Etchepare, M.; Vespa, P.M. Early cerebral metabolic crisis after TBI influences outcome despite adequate hemodynamic resuscitation. Neurocrit. Care 2012, 17 49-57.

16. Selwyn, R.; Hockenbury, N.; Jaiswal, S.; Mathur, S.; Armstrong, R.C.; Byrnes, K.R. Mild traumatic brain injury results in depressed cerebral glucose uptake: An FDG PET study. J. Neurotrauma 2013, 30, 1943-1953.

17. Matsushima, K.; Peng, M.; Velasco, C.; Schaefer, E.; Diaz-Arrastia, R.; Frankel, H. Glucose variability negatively impacts long-term functional outcome in patients with traumatic brain injury. J. Crit. Care 2012, 27, 125-131. 
18. Moro, N.; Ghavim, S.; Harris, N.G.; Hovda, D.A.; Sutton, R.L. Glucose administration after traumatic brain injury improves cerebral metabolism and reduces secondary neuronal injury. Brain Res. 2013, 1535, 124-136.

19. Merino, M.A.; Sahuquillo, J.; Borrull, A.; Poca, M.A.; Riveiro, M.; Exposito, L. Is lactate a good indicator of brain tissue hypoxia in the acute phase of traumatic brain injury? Results of a pilot study in 21 patients. Neurocirugia (Asturias) 2010, 21, 289-301.

20. Sala, N.; Suys, T.; Zerlauth, J.B.; Bouzat, P.; Messerer, M.; Bloch, J.; Levivier, M.; Magistretti, P.J.; Meuli, R.; Oddo, M. Cerebral extracellular lactate increase is predominantly nonischemic in patients with severe traumatic brain injury. J. Cereb. Blood Flow Metab. 2013, 33, 1815-1822.

21. Scafidi, S.; O’Brien, J.; Hopkins, I.; Robertson, C.; Fiskum, G.; McKenna, M. Delayed cerebral oxidative glucose metabolism after traumatic brain injury in young rats. J. Neurochem. 2009, 109, 189-197.

22. Werner, C.; Engelhard, K. Pathophysiology of traumatic brain injury. Br. J. Anaesth. 2007, 99, 4-9.

23. Rink, A.; Fung, K.M.; Trojanowski, J.Q.; Lee, V.M.; Neugebauer, E.; McIntosh, T.K. Evidence of apoptotic cell death after experimental traumatic brain injury in the rat. Am. J. Pathol. 1995, 147, 1575-1583.

24. Raghupathi, R.; Graham, D.I.; McIntosh, T.K. Apoptosis after traumatic brain injury. J. Neurotrauma 2000, 17, 927-938.

25. Bullock, R.; Zauner, A.; Woodward, J.J.; Myseros, J.; Choi, S.C.; Ward, J.D.; Marmarou, A.; Young, H.F. Factors affecting excitatory amino acid release following severe human head injury. J. Neurosurg. 1998, 89, 507-518.

26. Hinzman, J.M.; Thomas, T.C.; Quintero, J.E.; Gerhardt, G.A.; Lifshitz, J. Disruptions in the regulation of extracellular glutamate by neurons and glia in the rat striatum two days after diffuse brain injury. J. Neurotrauma 2012, 29, 1197-1208.

27. Mellergard, P.; Sjogren, F.; Hillman, J. The cerebral extracellular release of glycerol, glutamate, and FGF2 is increased in older patients following severe traumatic brain injury. J. Neurotrauma 2012, 29, 112-118.

28. Choi, D.W.; Maulucci-Gedde, M.; Kriegstein, A.R. Glutamate neurotoxicity in cortical cell culture. J. Neurosci. 1987, 7, 357-368.

29. Floyd, C.L.; Gorin, F.A.; Lyeth, B.G. Mechanical strain injury increases intracellular sodium and reverses $\mathrm{Na}^{+} / \mathrm{Ca}^{2+}$ exchange in cortical astrocytes. Glia 2005, 51, 35-46.

30. Wang, T.; Huang, X.J.; Van, K.C.; Went, G.T.; Nguyen, J.T.; Lyeth, B.G. Amantadine improves cognitive outcome and increases neuronal survival after fluid percussion traumatic brain injury in rats. J. Neurotrauma 2013, doi:10.1089/neu.2013.2917.

31. Han, R.Z.; Hu, J.J.; Weng, Y.C.; Li, D.F.; Huang, Y. NMDA receptor antagonist MK-801 reduces neuronal damage and preserves learning and memory in a rat model of traumatic brain injury. Neurosci. Bull. 2009, 25, 367-375.

32. Cherian, L.; Hlatky, R.; Robertson, C.S. Nitric oxide in traumatic brain injury. Brain Pathol. (Zurich) 2004, 14, 195-201. 
33. Kandasamy, R.; Kanti Pal, H.; Swamy, M.; Abdullah, J. Cerebrospinal fluid nitric oxide metabolite levels as a biomarker in severe traumatic brain injury. Int. J. Neurosci. 2013, 123, 385-391.

34. Dai, S.S.; Zhou, Y.G.; Li, W.; An, J.H.; Li, P.; Yang, N.; Chen, X.Y.; Xiong, R.P.; Liu, P.; Zhao, Y.; et al. Local glutamate level dictates adenosine A2A receptor regulation of neuroinflammation and traumatic brain injury. J. Neurosci. 2010, 30, 5802-5810.

35. Nicholls, D.G. A role for the mitochondrion in the protection of cells against calcium overload? Prog. Brain Res. 1985, 63, 97-106.

36. Xiong, Y.; Gu, Q.; Peterson, P.L.; Muizelaar, J.P.; Lee, C.P. Mitochondrial dysfunction and calcium perturbation induced by traumatic brain injury. J. Neurotrauma 1997, 14, 23-34.

37. Maciel, E.N.; Vercesi, A.E.; Castilho, R.F. Oxidative stress in $\mathrm{Ca}(2+)$-induced membrane permeability transition in brain mitochondria. J. Neurochem. 2001, 79, 1237-1245.

38. Singh, I.N.; Sullivan, P.G.; Deng, Y.; Mbye, L.H.; Hall, E.D. Time course of post-traumatic mitochondrial oxidative damage and dysfunction in a mouse model of focal traumatic brain injury: Implications for neuroprotective therapy. J. Cereb. Blood Flow Metab. 2006, 26, 1407-1418.

39. Darwish, R.S.; Amiridze, N.S. Detectable levels of cytochrome C and activated caspase-9 in cerebrospinal fluid after human traumatic brain injury. Neurocrit. Care 2010, 12, 337-341.

40. Signoretti, S.; Marmarou, A.; Aygok, G.A.; Fatouros, P.P.; Portella, G.; Bullock, R.M. Assessment of mitochondrial impairment in traumatic brain injury using high-resolution proton magnetic resonance spectroscopy. J. Neurosurg. 2008, 108, 42-52.

41. Diller, K.R.; Zhu, L. Hypothermia therapy for brain injury. Annu. Rev. Biomed. Eng. 2009, 11, 135-162.

42. Tomura, S.; de Rivero Vaccari, J.P.; Keane, R.W.; Bramlett, H.M.; Dietrich, W.D. Effects of therapeutic hypothermia on inflammasome signaling after traumatic brain injury. J. Cereb. Blood Flow Metab. 2012, 32, 1939-1947.

43. Bratton, S.L.; Chestnut, R.M.; Ghajar, J.; McConnell Hammond, F.F.; Harris, O.A.; Hartl, R.; Manley, G.T.; Nemecek, A.; Newell, D.W.; Rosenthal, G.; et al. Guidelines for the management of severe traumatic brain injury. III. Prophylactic hypothermia. J. Neurotrauma 2007, 24, S21-S25.

44. Soukup, J.; Zauner, A.; Doppenberg, E.M.; Menzel, M.; Gilman, C.; Bullock, R.; Young, H.F. Relationship between brain temperature, brain chemistry and oxygen delivery after severe human head injury: The effect of mild hypothermia. Neurol. Res. 2002, 24, 161-168.

45. Bukur, M.; Kurtovic, S.; Berry, C.; Tanios, M.; Ley, E.J.; Salim, A. Pre-hospital hypothermia is not associated with increased survival after traumatic brain injury. J. Surg. Res. 2012, 175, 24-29.

46. Rubiano, A.M.; Sanchez, A.I.; Estebanez, G.; Peitzman, A.; Sperry, J.; Puyana, J.C. The effect of admission spontaneous hypothermia on patients with severe traumatic brain injury. Injury 2013, 44, 1219-1225.

47. Childs, C.; Lunn, K.W. Clinical review: Brain-body temperature differences in adults with severe traumatic brain injury. Criti. Care (Lond.) 2013, 17, 222. 
48. Clifton, G.L.; Valadka, A.; Zygun, D.; Coffey, C.S.; Drever, P.; Fourwinds, S.; Janis, L.S.; Wilde, E.; Taylor, P.; Harshman, K.; et al. Very early hypothermia induction in patients with severe brain injury (the National Acute Brain Injury Study: Hypothermia II): A randomised trial. Lancet Neurol. 2011, 10, 131-139.

49. Suehiro, E.M.D.P.D.; Koizumi, H.; Kunitsugu, I.; Fujisawa, H.; Suzuki, M. Survey of brain temperature management in patients with traumatic brain injury in the Japan Neurotrauma Data Bank. J. Neurotrauma 2013, doi:10.1089/neu.2013.3057.

50. Zhao, Q.J.; Zhang, X.G.; Wang, L.X. Mild hypothermia therapy reduces blood glucose and lactate and improves neurologic outcomes in patients with severe traumatic brain injury. J. Crit. Care 2011, 26, 311-315.

51. Fox, J.L.; Vu, E.N.; Doyle-Waters, M.; Brubacher, J.R.; Abu-Laban, R.; Hu, Z. Prophylactic hypothermia for traumatic brain injury: A quantitative systematic review. CJEM 2010, 12, 355-364.

52. Lee, H.C.; Chuang, H.C.; Cho, D.Y.; Cheng, K.F.; Lin, P.H.; Chen, C.C. Applying cerebral hypothermia and brain oxygen monitoring in treating severe traumatic brain injury. World Neurosurg. 2010, 74, 654-660.

53. Honda, M.; Sase, S.; Yokota, K.; Ichibayashi, R.; Yoshihara, K.; Masuda, H.; Uekusa, H.; Nomoto, J.; Sugo, N.; Kishi, T.; et al. Early cerebral circulation disturbance in patients suffering from different types of severe traumatic brain injury: A xenon CT and perfusion CT study. Acta Neurochir. Suppl. 2013, 118, 259-263.

54. Empey, P.E.; de Mendizabal, N.V.; Bell, M.J.; Bies, R.R.; Anderson, K.B.; Kochanek, P.M.; Adelson, P.D.; Poloyac, S.M. Therapeutic hypothermia decreases phenytoin elimination in children with traumatic brain injury. Crit. Care Med. 2013, 41, 2379-2387.

55. Andrews, P.J.; Sinclair, L.H.; Harris, B.; Baldwin, M.J.; Battison, C.G.; Rhodes, J.K.; Murray, G.; de Backer, D. Study of therapeutic hypothermia (32 to 35 degrees C) for intracranial pressure reduction after traumatic brain injury (the Eurotherm3235Trial): Outcome of the pilot phase of the trial. Trials 2013, 14, 277.

56. Huang, L.; Obenaus, A. Hyperbaric oxygen therapy for traumatic brain injury. Med. Gas Res. 2011, $1,21$.

57. Menzel, M.; Doppenberg, E.M.; Zauner, A.; Soukup, J.; Reinert, M.M.; Clausen, T.; Brockenbrough, P.B.; Bullock, R. Cerebral oxygenation in patients after severe head injury: Monitoring and effects of arterial hyperoxia on cerebral blood flow, metabolism and intracranial pressure. J. Neurosurg. Anesthesiol. 1999, 11, 240-251.

58. McDonagh, M.; Helfand, M.; Carson, S.; Russman, B.S. Hyperbaric oxygen therapy for traumatic brain injury: A systematic review of the evidence. Arch. Phys. Med. Rehabil. 2004, 85, 1198-1204.

59. Sahni, T.; Jain, M.; Prasad, R.; Sogani, S.K.; Singh, V.P. Use of hyperbaric oxygen in traumatic brain injury: Retrospective analysis of data of 20 patients treated at a tertiary care centre. Br. J. Neurosurg. 2012, 26, 202-207.

60. Lin, J.W.; Tsai, J.T.; Lee, L.M.; Lin, C.M.; Hung, C.C.; Hung, K.S.; Chen, W.Y.; Wei, L.; Ko, C.P.; Su, Y.K.; et al. Effect of hyperbaric oxygen on patients with traumatic brain injury. Acta Neurochir. Suppl. 2008, 101, 145-149. 
61. Rockswold, S.B.; Rockswold, G.L.; Zaun, D.A.; Liu, J. A prospective, randomized Phase II clinical trial to evaluate the effect of combined hyperbaric and normobaric hyperoxia on cerebral metabolism, intracranial pressure, oxygen toxicity, and clinical outcome in severe traumatic brain injury. J. Neurosurg. 2013, 118, 1317-1328.

62. Rockswold, S.B.; Rockswold, G.L.; Zaun, D.A.; Zhang, X.; Cerra, C.E.; Bergman, T.A.; Liu, J. A prospective, randomized clinical trial to compare the effect of hyperbaric to normobaric hyperoxia on cerebral metabolism, intracranial pressure, and oxygen toxicity in severe traumatic brain injury. J. Neurosurg. 2010, 112, 1080-1094.

63. Wolf, G.; Cifu, D.; Baugh, L.; Carne, W.; Profenna, L. The effect of hyperbaric oxygen on symptoms after mild traumatic brain injury. J. Neurotrauma 2012, 29, 2606-2612.

64. Harch, P.G.; Andrews, S.R.; Fogarty, E.F.; Amen, D.; Pezzullo, J.C.; Lucarini, J.; Aubrey, C.; Taylor, D.V.; Staab, P.K.; van Meter, K.W. A phase I study of low-pressure hyperbaric oxygen therapy for blast-induced post-concussion syndrome and post-traumatic stress disorder. J. Neurotrauma 2012, 29, 168-185.

65. Micarelli, A.; Jacobsson, H.; Larsson, S.A.; Jonsson, C.; Pagani, M. Neurobiological insight into hyperbaric hyperoxia. Acta Physiol. (Oxf.) 2013, doi:10.1111/apha.12116.

66. Bulte, D.P.; Chiarelli, P.A.; Wise, R.G.; Jezzard, P. Cerebral perfusion response to hyperoxia. J. Cereb. Blood Flow Metab. 2007, 27, 69-75.

67. Ahn, E.S.; Robertson, C.L.; Vereczki, V.; Hoffman, G.E.; Fiskum, G. Normoxic ventilatory resuscitation following controlled cortical impact reduces peroxynitrite-mediated protein nitration in the hippocampus. J. Neurosurg. 2008, 108, 124-131.

68. Puccio, A.M.; Hoffman, L.A.; Bayir, H.; Zullo, T.G.; Fischer, M.; Darby, J.; Alexander, S.; Dixon, C.E.; Okonkwo, D.O.; Kochanek, P.M. Effect of short periods of normobaric hyperoxia on local brain tissue oxygenation and cerebrospinal fluid oxidative stress markers in severe traumatic brain injury. J. Neurotrauma 2009, 26, 1241-1249.

69. Dardiotis, E.; Karanikas, V.; Paterakis, K.; Fountas, K.; Hadjigeorgiou, G.M. Traumatic Brain Injury and Inflammation: Emerging Role of Innate and Adaptive Immunity. In Brain Injury-Pathogenesis, Monitoring, Recovery and Management; Agrawal, A., Ed.; InTech: Rijeka, Croatia, 2012.

70. Das, M.; Leonardo, C.C.; Rangooni, S.; Pennypacker, K.R.; Mohapatra, S.; Mohapatra, S.S. Lateral fluid percussion injury of the brain induces CCL20 inflammatory chemokine expression in rats. J. Neuroinflamm. 2011, 8, 148.

71. Ransohoff, R.M. The chemokine system in neuroinflammation: An update. J. Infect. Dis. 2002, 186, S152-S156.

72. Otto, V.I.; Stahel, P.F.; Rancan, M.; Kariya, K.; Shohami, E.; Yatsiv, I.; Eugster, H.P.; Kossmann, T.; Trentz, O.; Morganti-Kossmann, M.C. Regulation of chemokines and chemokine receptors after experimental closed head injury. Neuroreport 2001, 12, 2059-2064.

73. Rhodes, J. Peripheral immune cells in the pathology of traumatic brain injury? Curr. Opin. Crit. Care 2011, 17, 122-130.

74. Tompkins, P.; Tesiram, Y.; Lerner, M.; Gonzalez, L.P.; Lightfoot, S.; Rabb, C.H.; Brackett, D.J. Brain injury: Neuro-inflammation, cognitive deficit, and magnetic resonance imaging in a model of blast induced traumatic brain injury. J. Neurotrauma 2013, 30, 1888-1897. 
75. Liao, Y.; Liu, P.; Guo, F.; Zhang, Z.Y.; Zhang, Z. Oxidative burst of circulating neutrophils following traumatic brain injury in human. PLoS One 2013, 8, e68963.

76. Yu, C.H.; Yhee, J.Y.; Kim, J.H.; Im, K.S.; Kim, N.H.; Jung, D.I.; Lee, H.C.; Chon, S.K.; Sur, J.H. Pro- and anti-inflammatory cytokine expression and histopathological characteristics in canine brain with traumatic brain injury. J. Vet. Sci. 2011, 12, 299-301.

77. Ziebell, J.M.; Morganti-Kossmann, M.C. Involvement of pro- and anti-inflammatory cytokines and chemokines in the pathophysiology of traumatic brain injury. Neurotherapeutics 2010, 7, 22-30.

78. Liu, H.D.; Li, W.; Chen, Z.R.; Hu, Y.C.; Zhang, D.D.; Shen, W.; Zhou, M.L.; Zhu, L.; Hang, C.H. Expression of the NLRP3 inflammasome in cerebral cortex after traumatic brain injury in a rat model. Neurochem. Res. 2013, 38, 2072-2083.

79. Frugier, T.; Morganti-Kossmann, M.C.; O’Reilly, D.; McLean, C.A. In situ detection of inflammatory mediators in post mortem human brain tissue after traumatic injury. J. Neurotrauma 2010, 27, 497-507.

80. Kaushik, D.K.; Thounaojam, M.C.; Kumawat, K.L.; Gupta, M.; Basu, A. Interleukin-1 $\beta$ orchestrates underlying inflammatory responses in microglia via Kruppel-like factor 4. J. Neurochem. 2013, 127, 233-244.

81. Ralay Ranaivo, H.; Zunich, S.M.; Choi, N.; Hodge, J.N.; Wainwright, M.S. Mild stretch-induced injury increases susceptibility to interleukin-1beta-induced release of matrix metalloproteinase- 9 from astrocytes. J. Neurotrauma 2011, 28, 1757-1766.

82. Roberts, D.J.; Jenne, C.N.; Leger, C.; Kramer, A.H.; Gallagher, C.N.; Todd, S.; Parney, I.F.; Doig, C.J.; Yong, V.W.; Kubes, P.; et al. Association between the cerebral inflammatory and matrix metalloproteinase responses after severe traumatic brain injury in humans. J. Neurotrauma 2013, 30, 1727-1736.

83. Belarbi, K.; Jopson, T.; Tweedie, D.; Arellano, C.; Luo, W.; Greig, N.H.; Rosi, S. TNF- $\alpha$ protein synthesis inhibitor restores neuronal function and reverses cognitive deficits induced by chronic neuroinflammation. J. Neuroinflamm. 2012, 9, 23.

84. Waters, R.J.; Murray, G.D.; Teasdale, G.M.; Stewart, J.; Day, I.; Lee, R.J.; Nicoll, J.A. Cytokine gene polymorphisms and outcome after traumatic brain injury. J. Neurotrauma 2013, 30, 1710-1716.

85. Elahi, M.M.; Asotra, K.; Matata, B.M.; Mastana, S.S. Tumor necrosis factor $\alpha-308$ gene locus promoter polymorphism: An analysis of association with health and disease. Biochim. Biophys. Acta 2009, 1792, 163-172.

86. Alexander, J.J.; Jacob, A.; Cunningham, P.; Hensley, L.; Quigg, R.J. TNF is a key mediator of septic encephalopathy acting through its receptor, TNF receptor-1. Neurochem. Int. 2008, 52, 447-456.

87. Satoh, J.; Tabunoki, H.; Yamamura, T.; Arima, K.; Konno, H. Human astrocytes express aquaporin-1 and aquaporin-4 in vitro and in vivo. Neuropathology 2007, 27, 245-256.

88. Fukuda, A.M.; Pop, V.; Spagnoli, D.; Ashwal, S.; Obenaus, A.; Badaut, J. Delayed increase of astrocytic aquaporin 4 after juvenile traumatic brain injury: Possible role in edema resolution? Neuroscience 2012, 222, 366-378.

89. Dalle Lucca, J.J.; Chavko, M.; Dubick, M.A.; Adeeb, S.; Falabella, M.J.; Slack, J.L.; McCarron, R.; Li, Y. Blast-induced moderate neurotrauma (BINT) elicits early complement activation and tumor necrosis factor $\alpha(\mathrm{TNF} \alpha)$ release in a rat brain. J. Neurol. Sci. 2012, 318, 146-154. 
90. Lo Pizzo, M.; Schiera, G.; Di Liegro, I.; Di Liegro, C.M.; Pal, J.; Czeiter, E.; Sulyok, E.; Doczi, T. Aquaporin-4 distribution in control and stressed astrocytes in culture and in the cerebrospinal fluid of patients with traumatic brain injuries. Neurol. Sci. 2013, 34, 1309-1314.

91. Shenaq, M.; Kassem, H.; Peng, C.; Schafer, S.; Ding, J.Y.; Fredrickson, V.; Guthikonda, M.; Kreipke, C.W.; Rafols, J.A.; Ding, Y. Neuronal damage and functional deficits are ameliorated by inhibition of aquaporin and HIF $1 \alpha$ after traumatic brain injury (TBI). J. Neurol. Sci. 2012, $323,134-140$.

92. Lu, D.C.; Zador, Z.; Yao, J.; Fazlollahi, F.; Manley, G.T. Aquaporin-4 reduces post-traumatic seizure susceptibility by promoting astrocytic glial scar formation in mice. J. Neurotrauma 2011, doi:10.1089/neu.2011.2114.

93. Timaru-Kast, R.; Luh, C.; Gotthardt, P.; Huang, C.; Schafer, M.K.; Engelhard, K.; Thal, S.C. Influence of age on brain edema formation, secondary brain damage and inflammatory response after brain trauma in mice. PLoS One 2012, 7, e43829.

94. Tasker, R.C.; Westland, A.G.; White, D.K.; Williams, G.B. Corpus callosum and inferior forebrain white matter microstructure are related to functional outcome from raised intracranial pressure in child traumatic brain injury. Dev. Neurosci. 2010, 32, 374-384.

95. Lloyd, E.; Somera-Molina, K.; van Eldik, L.J.; Watterson, D.M.; Wainwright, M.S. Suppression of acute proinflammatory cytokine and chemokine upregulation by post-injury administration of a novel small molecule improves long-term neurologic outcome in a mouse model of traumatic brain injury. J. Neuroinflamm. 2008, 5, 28.

96. Marklund, N.; Bakshi, A.; Castelbuono, D.J.; Conte, V.; McIntosh, T.K. Evaluation of pharmacological treatment strategies in traumatic brain injury. Curr. Pharm. Des. 2006, 12, 1645-1680.

97. Savola, O.; Pyhtinen, J.; Leino, T.K.; Siitonen, S.; Niemela, O.; Hillbom, M. Effects of head and extracranial injuries on serum protein S100B levels in trauma patients. J. Trauma 2004, 56, 1229-1234; discussion 1234.

98. Hernandez-Ontiveros, D.G.; Tajiri, N.; Acosta, S.; Giunta, B.; Tan, J.; Borlongan, C.V. Microglia activation as a biomarker for traumatic brain injury. Front. Neurol. 2013, 4, 30.

99. Bratton, S.L.; Chestnut, R.M.; Ghajar, J.; McConnell Hammond, F.F.; Harris, O.A.; Hartl, R.; Manley, G.T.; Nemecek, A.; Newell, D.W.; Rosenthal, G.; et al. Guidelines for the management of severe traumatic brain injury. VII. Intracranial pressure monitoring technology. J. Neurotrauma 2007, 24, S45-S54.

100. Roberts, I.; Yates, D.; Sandercock, P.; Farrell, B.; Wasserberg, J.; Lomas, G.; Cottingham, R.; Svoboda, P.; Brayley, N.; Mazairac, G.; et al. Effect of intravenous corticosteroids on death within 14 days in 10008 adults with clinically significant head injury (MRC CRASH trial): Randomised placebo-controlled trial. Lancet 2004, 364, 1321-1328.

101. Attella, M.J.; Nattinville, A.; Stein, D.G. Hormonal state affects recovery from frontal cortex lesions in adult female rats. Behav. Neural boil. 1987, 48, 352-367.

102. Meffre, D.; Labombarda, F.; Delespierre, B.; Chastre, A.; de Nicola, A.F.; Stein, D.G.; Schumacher, M.; Guennoun, R. Distribution of membrane progesterone receptor alpha in the male mouse and rat brain and its regulation after traumatic brain injury. Neuroscience 2013, 231, $111-124$. 
103. Wright, D.W.; Bauer, M.E.; Hoffman, S.W.; Stein, D.G. Serum progesterone levels correlate with decreased cerebral edema after traumatic brain injury in male rats. J. Neurotrauma 2001, 18, 901-909.

104. Cutler, S.M.; Cekic, M.; Miller, D.M.; Wali, B.; VanLandingham, J.W.; Stein, D.G. Progesterone improves acute recovery after traumatic brain injury in the aged rat. J. Neurotrauma 2007, 24 1475-1486.

105. Guo, Q.; Sayeed, I.; Baronne, L.M.; Hoffman, S.W.; Guennoun, R.; Stein, D.G. Progesterone administration modulates AQP4 expression and edema after traumatic brain injury in male rats. Exp. Neurol. 2006, 198, 469-478.

106. Li, Z.; Wang, B.; Kan, Z.; Zhang, B.; Yang, Z.; Chen, J.; Wang, D.; Wei, H.; Zhang, J.N.; Jiang, R. Progesterone increases circulating endothelial progenitor cells and induces neural regeneration after traumatic brain injury in aged rats. $J$. Neurotrauma 2012, 29, 343-353.

107. Roof, R.L.; Hoffman, S.W.; Stein, D.G. Progesterone protects against lipid peroxidation following traumatic brain injury in rats. Mol. Chem. Neuropathol. 1997, 31, 1-11.

108. Djebaili, M.; Hoffman, S.W.; Stein, D.G. Allopregnanolone and progesterone decrease cell death and cognitive deficits after a contusion of the rat pre-frontal cortex. Neuroscience 2004, 123, 349-359.

109. Djebaili, M.; Guo, Q.; Pettus, E.H.; Hoffman, S.W.; Stein, D.G. The neurosteroids progesterone and allopregnanolone reduce cell death, gliosis, and functional deficits after traumatic brain injury in rats. $J$. Neurotrauma 2005, 22, 106-118.

110. Yao, X.L.; Liu, J.; Lee, E.; Ling, G.S.; McCabe, J.T. Progesterone differentially regulates pro- and anti-apoptotic gene expression in cerebral cortex following traumatic brain injury in rats. J. Neurotrauma 2005, 22, 656-668.

111. O’Connor, C.A.; Cernak, I.; Johnson, F.; Vink, R. Effects of progesterone on neurologic and morphologic outcome following diffuse traumatic brain injury in rats. Exp. Neurol. 2007, 205, 145-153.

112. Sarkaki, A.R.; Khaksari Haddad, M.; Soltani, Z.; Shahrokhi, N.; Mahmoodi, M. Time- and dose-dependent neuroprotective effects of sex steroid hormones on inflammatory cytokines after a traumatic brain injury. J. Neurotrauma 2013, 30, 47-54.

113. Barha, C.K.; Ishrat, T.; Epp, J.R.; Galea, L.A.; Stein, D.G. Progesterone treatment normalizes the levels of cell proliferation and cell death in the dentate gyrus of the hippocampus after traumatic brain injury. Exp. Neurol. 2011, 231, 72-81.

114. Tang, H.; Hua, F.; Wang, J.; Sayeed, I.; Wang, X.; Chen, Z.; Yousuf, S.; Atif, F.; Stein, D.G. Progesterone and vitamin D: Improvement after traumatic brain injury in middle-aged rats. Horm. Behav. 2013, 64, 527-538.

115. Wright, D.W.; Kellermann, A.L.; Hertzberg, V.S.; Clark, P.L.; Frankel, M.; Goldstein, F.C.; Salomone, J.P.; Dent, L.L.; Harris, O.A.; Ander, D.S.; et al. ProTECT: A randomized clinical trial of progesterone for acute traumatic brain injury. Ann. Emerg. Med. 2007, 49, 391-402.

116. Shakeri, M.; Boustani, M.R.; Pak, N.; Panahi, F.; Salehpour, F.; Lotfinia, I.; Meshkini, A.; Daghighi, S.; Vahedi, P.; Khani, M.; et al. Effect of progesterone administration on prognosis of patients with diffuse axonal injury due to severe head trauma. Clin. Neurol. Neurosurg. 2013, 115, 2019-2022. 
117. Ma, J.; Huang, S.; Qin, S.; You, C. Progesterone for acute traumatic brain injury. Cochrane Database Syst. Rev. 2012, 10, doi:10.1002/14651858.CD008409.pub3.

118. Aminmansour, B.; Nikbakht, H.; Ghorbani, A.; Rezvani, M.; Rahmani, P.; Torkashvand, M.; Nourian, M.; Moradi, M. Comparison of the administration of progesterone versus progesterone and vitamin D in improvement of outcomes in patients with traumatic brain injury: A randomized clinical trial with placebo group. Adv. Biomed. Res. 2012, 1, 58.

119. Bratton, S.L.; Chestnut, R.M.; Ghajar, J.; McConnell Hammond, F.F.; Harris, O.A.; Hartl, R.; Manley, G.T.; Nemecek, A.; Newell, D.W.; Rosenthal, G.; et al. Guidelines for the management of severe traumatic brain injury. II. Hyperosmolar therapy. J. Neurotrauma 2007, 24, S14-S20.

120. Muizelaar, J.P.; Lutz, H.A., 3rd; Becker, D.P. Effect of mannitol on ICP and CBF and correlation with pressure autoregulation in severely head-injured patients. J. Neurosurg. 1984, 61, 700-706.

121. Rickard, A.C.; Smith, J.E.; Newell, P.; Bailey, A.; Kehoe, A.; Mann, C. Salt or sugar for your injured brain? A meta-analysis of randomised controlled trials of mannitol versus hypertonic sodium solutions to manage raised intracranial pressure in traumatic brain injury. Emerg. Med. J. 2013, doi:10.1136/emermed-2013-202679.

122. Ichai, C.; Payen, J.F.; Orban, J.C.; Quintard, H.; Roth, H.; Legrand, R.; Francony, G.; Leverve, X.M. Half-molar sodium lactate infusion to prevent intracranial hypertensive episodes in severe traumatic brain injured patients: A randomized controlled trial. Intensive Care Med. 2013, 39, 1413-1422.

123. Eskandari, R.; Filtz, M.R.; Davis, G.E.; Hoesch, R.E. Effective treatment of refractory intracranial hypertension after traumatic brain injury with repeated boluses of $14.6 \%$ hypertonic saline. J. Neurosurg. 2013, 119, 338-346.

124. Oddo, M.; Levine, J.M.; Frangos, S.; Carrera, E.; Maloney-Wilensky, E.; Pascual, J.L.; Kofke, W.A.; Mayer, S.A.; LeRoux, P.D. Effect of mannitol and hypertonic saline on cerebral oxygenation in patients with severe traumatic brain injury and refractory intracranial hypertension. J. Neurol. Neurosurg. Psychiatry 2009, 80, 916-920.

125. Scalfani, M.T.; Dhar, R.; Zazulia, A.R.; Videen, T.O.; Diringer, M.N. Effect of osmotic agents on regional cerebral blood flow in traumatic brain injury. J. Crit. Care 2012, 526, e7-e12.

126. Cottenceau, V.; Masson, F.; Mahamid, E.; Petit, L.; Shik, V.; Sztark, F.; Zaaroor, M.; Soustiel, J.F. Comparison of effects of equiosmolar doses of mannitol and hypertonic saline on cerebral blood flow and metabolism in traumatic brain injury. J. Neurotrauma 2011, 28, 2003-2012.

127. Williams, R.F.; Magnotti, L.J.; Croce, M.A.; Hargraves, B.B.; Fischer, P.E.; Schroeppel, T.J.; Zarzaur, B.L.; Muhlbauer, M.; Timmons, S.D.; Fabian, T.C. Impact of decompressive craniectomy on functional outcome after severe traumatic brain injury. J. Trauma 2009, 66, 1570-1574; discussion 1574-1576.

128. Huang, Y.H.; Lee, T.C.; Lee, T.H.; Liao, C.C.; Sheehan, J.; Kwan, A.L. Thirty-day mortality in traumatically brain-injured patients undergoing decompressive craniectomy. J. Neurosurg. 2013, 118, 1329-1335. 
129. Yuan, Q.; Liu, H.; Wu, X.; Sun, Y.; Hu, J. Comparative study of decompressive craniectomy in traumatic brain injury with or without mass lesion. Br. J. Neurosurg. 2013, 27, 483-488.

130. Ban, S.P.; Son, Y.J.; Yang, H.J.; Chung, Y.S.; Lee, S.H.; Han, D.H. Analysis of complications following decompressive craniectomy for traumatic brain injury. J. Korean Neurosurg. Soc. 2010, 48, 244-250.

131. Wang, E.W.; Huang, J.H. Understanding and treating blast traumatic brain injury in the combat theater. Neurol. Res. 2013, 35, 285-289.

132. Soustiel, J.F.; Sviri, G.E.; Mahamid, E.; Shik, V.; Abeshaus, S.; Zaaroor, M. Cerebral blood flow and metabolism following decompressive craniectomy for control of increased intracranial pressure. Neurosurgery 2010, 67, 65-72; discussion 72.

133. Weiner, G.M.; Lacey, M.R.; Mackenzie, L.; Shah, D.P.; Frangos, S.G.; Grady, M.S.; Kofke, A.; Levine, J.; Schuster, J.; Le Roux, P.D. Decompressive craniectomy for elevated intracranial pressure and its effect on the cumulative ischemic burden and therapeutic intensity levels after severe traumatic brain injury. Neurosurgery 2010, 66, 1111-1118; discussion 1118-1119.

134. Cooper, D.J.; Rosenfeld, J.V.; Murray, L.; Arabi, Y.M.; Davies, A.R.; D’Urso, P.; Kossmann, T.; Ponsford, J.; Seppelt, I.; Reilly, P.; et al. Decompressive craniectomy in diffuse traumatic brain injury. N. Engl. J. Med. 2011, 364, 1493-1502.

135. Honeybul, S.; Ho, K.M.; Lind, C.R. What can be learned from the DECRA study. World Neurosurg. 2013, 79, 159-161.

136. Cianchi, G.; Bonizzoli, M.; Zagli, G.; di Valvasone, S.; Biondi, S.; Ciapetti, M.; Perretta, L.; Mariotti, F.; Peris, A. Late decompressive craniectomyafter traumatic brain injury: Neurological outcome at 6 months after ICU discharge. J. Trauma Manag. Outcomes 2012, 6, 8.

137. Whitmore, R.G.; Thawani, J.P.; Grady, M.S.; Levine, J.M.; Sanborn, M.R.; Stein, S.C. Is aggressive treatment of traumatic brain injury cost-effective? J. Neurosurg. 2012, 116, 1106-1113.

138. Ho, K.M.; Honeybul, S.; Lind, C.R.; Gillett, G.R.; Litton, E. Cost-effectiveness of decompressive craniectomy as a lifesaving rescue procedure for patients with severe traumatic brain injury. J. Trauma 2011, 71, 1637-1644; discussion 1644.

139. Lemcke, J.; Ahmadi, S.; Meier, U. Outcome of patients with severe head injury after decompressive craniectomy. Acta Neurochir. Suppl. 2010, 106, 231-233.

140. Tomkins, O.; Feintuch, A.; Benifla, M.; Cohen, A.; Friedman, A.; Shelef, I. Blood-brain barrier breakdown following traumatic brain injury: A possible role in posttraumatic epilepsy. Cardiovasc. Psychiatry Neurol. 2011, 2011, 765923.

141. Dudek, F.E.; Spitz, M. Hypothetical mechanisms for the cellular and neurophysiologic basis of secondary epileptogenesis: Proposed role of synaptic reorganization. J. Clin. Neurophysiol. 1997, 14, 90-101.

142. Lei, Z.; Deng, P.; Li, J.; Xu, Z.C. Alterations of A-type potassium channels in hippocampal neurons after traumatic brain injury. J. Neurotrauma 2012, 29, 235-245.

143. Hu, B.; Liu, C.; Bramlett, H.; Sick, T.J.; Alonso, O.F.; Chen, S.; Dietrich, W.D. Changes in trkB-ERK1/2-CREB/Elk-1 pathways in hippocampal mossy fiber organization after traumatic brain injury. J. Cereb. Blood Flow Metab. 2004, 24, 934-943.

144. Aungst, S.; England, P.M.; Thompson, S.M. Critical role of trkB receptors in reactive axonal sprouting and hyperexcitability after axonal injury. J. Neurophysiol. 2013, 109, 813-824. 
145. Hunt, R.F.; Scheff, S.W.; Smith, B.N. Posttraumatic epilepsy after controlled cortical impact injury in mice. Exp. Neurol. 2009, 215, 243-252.

146. Hunt, R.F.; Scheff, S.W.; Smith, B.N. Regionally localized recurrent excitation in the dentate gyrus of a cortical contusion model of posttraumatic epilepsy. J. Neurophysiol. 2010, 103, $1490-1500$.

147. Hunt, R.F.; Haselhorst, L.A.; Schoch, K.M.; Bach, E.C.; Rios-Pilier, J.; Scheff, S.W.; Saatman, K.E.; Smith, B.N. Posttraumatic mossy fiber sprouting is related to the degree of cortical damage in three mouse strains. Epilepsy Res. 2012, 99, 167-170.

148. Swartz, B.E.; Houser, C.R.; Tomiyasu, U.; Walsh, G.O.; DeSalles, A.; Rich, J.R.; Delgado-Escueta, A. Hippocampal cell loss in posttraumatic human epilepsy. Epilepsia 2006, 47, 1373-1382.

149. Han, X.; Tong, J.; Zhang, J.; Farahvar, A.; Wang, E.; Yang, J.; Samadani, U.; Smith, D.H.; Huang, J.H. Imipramine treatment improves cognitive outcome associated with enhanced hippocampal neurogenesis after traumatic brain injury in mice. J. Neurotrauma 2011, 28, 995-1007.

150. Tong, J.; Liu, W.; Wang, X.; Han, X.; Hyrien, O.; Samadani, U.; Smith, D.H.; Huang, J.H. Inhibition of Nogo-66 receptor 1 enhances recovery of cognitive function after traumatic brain injury in mice. J. Neurotrauma 2013, 30, 247-258.

151. Pavlov, I.; Huusko, N.; Drexel, M.; Kirchmair, E.; Sperk, G.; Pitkanen, A.; Walker, M.C. Progressive loss of phasic, but not tonic, GABAA receptor-mediated inhibition in dentate granule cells in a model of post-traumatic epilepsy in rats. Neuroscience 2011, 194, 208-219.

152. Golarai, G.; Greenwood, A.C.; Feeney, D.M.; Connor, J.A. Physiological and structural evidence for hippocampal involvement in persistent seizure susceptibility after traumatic brain injury. J. Neurosci. 2001, 21, 8523-8537.

153. Huusko, N.; Romer, C.; Ndode-Ekane, X.E.; Lukasiuk, K.; Pitkanen, A. Loss of hippocampal interneurons and epileptogenesis: A comparison of two animal models of acquired epilepsy. Brain Struct. Funct. 2013, doi:10.1007/s00429-013-0644-1.

154. Zhang, B.L.; Chen, X.; Tan, T.; Yang, Z.; Carlos, D.; Jiang, R.C.; Zhang, J.N. Traumatic brain injury impairs synaptic plasticity in hippocampus in rats. Chin. Med. J. 2011, 124, 740-745.

155. Shultz, S.R.; Cardamone, L.; Liu, Y.R.; Hogan, R.E.; Maccotta, L.; Wright, D.K.; Zheng, P.; Koe, A.; Gregoire, M.C.; Williams, J.P.; et al. Can structural or functional changes following traumatic brain injury in the rat predict epileptic outcome? Epilepsia 2013, 54, 1240-1250.

156. Vespa, P.M.; McArthur, D.L.; Xu, Y.; Eliseo, M.; Etchepare, M.; Dinov, I.; Alger, J.; Glenn, T.P.; Hovda, D. Nonconvulsive seizures after traumatic brain injury are associated with hippocampal atrophy. Neurology 2010, 75, 792-798.

157. Yang, L.; Afroz, S.; Michelson, H.B.; Goodman, J.H.; Valsamis, H.A.; Ling, D.S. Spontaneous epileptiform activity in rat neocortex after controlled cortical impact injury. $J$. Neurotrauma 2010, 27, 1541-1548.

158. Glotzner, F.L.; Haubitz, I.; Miltner, F.; Kapp, G.; Pflughaupt, K.W. Seizure prevention using carbamazepine following severe brain injuries. Neurochirurgia 1983, 26, 66-79.

159. Pechadre, J.C.; Lauxerois, M.; Colnet, G.; Commun, C.; Dimicoli, C.; Bonnard, M.; Gibert, J.; Chabannes, J. Prevention of late post-traumatic epilepsy by phenytoin in severe brain injuries. 2 years' follow-up. Presse Med. 1991, 20, 841-845. 
160. Temkin, N.R.; Dikmen, S.S.; Winn, H.R. Management of head injury. Posttraumatic seizures. Neurosurg. Clin. N. Am. 1991, 2, 425-435.

161. Temkin, N.R.; Dikmen, S.S.; Wilensky, A.J.; Keihm, J.; Chabal, S.; Winn, H.R. A randomized, double-blind study of phenytoin for the prevention of post-traumatic seizures. N. Engl. J. Med. 1990, 323, 497-502.

162. Yablon, S.A. Posttraumatic seizures. Arch. Phys. Med. Rehabil. 1993, 74, 983-1001.

163. Bratton, S.L.; Chestnut, R.M.; Ghajar, J.; McConnell Hammond, F.F.; Harris, O.A.; Hartl, R.; Manley, G.T.; Nemecek, A.; Newell, D.W.; Rosenthal, G.; et al. Guidelines for the management of severe traumatic brain injury. XIII. Antiseizure prophylaxis. J. Neurotrauma 2007, 24, S83-S86.

164. Torbic, H.; Forni, A.A.; Anger, K.E.; Degrado, J.R.; Greenwood, B.C. Use of antiepileptics for seizure prophylaxis after traumatic brain injury. Am. J. Health-Syst. Pharm. 2013, 70, 759-766.

165. Lynch, B.A.; Lambeng, N.; Nocka, K.; Kensel-Hammes, P.; Bajjalieh, S.M.; Matagne, A.; Fuks, B. The synaptic vesicle protein SV2A is the binding site for the antiepileptic drug levetiracetam. Proc. Natl. Acad. Sci. USA 2004, 101, 9861-9866.

166. Vogl, C.; Mochida, S.; Wolff, C.; Whalley, B.J.; Stephens, G.J. The synaptic vesicle glycoprotein 2A ligand levetiracetam inhibits presynaptic $\mathrm{Ca}^{2+}$ channels through an intracellular pathway. Mol. Pharmacol. 2012, 82, 199-208.

167. Zou, H.; Brayer, S.W.; Hurwitz, M.; Niyonkuru, C.; Fowler, L.E.; Wagner, A.K. Neuroprotective, neuroplastic, and neurobehavioral effects of daily treatment with levetiracetam in experimental traumatic brain injury. Neurorehabil. Neural Repair 2013, 27, 878-888.

168. Pearl, P.L.; McCarter, R.; McGavin, C.L.; Yu, Y.; Sandoval, F.; Trzcinski, S.; Atabaki, S.M.; Tsuchida, T.; van den Anker, J.; He, J.; et al. Results of phase II levetiracetam trial following acute head injury in children at risk for posttraumatic epilepsy. Epilepsia 2013, 54, e135-e137.

169. Zafar, S.N.; Khan, A.A.; Ghauri, A.A.; Shamim, M.S. Phenytoin versus Leviteracetam for seizure prophylaxis after brain injury-A meta analysis. BMC Neurol. 2012, 12, 30.

170. Steinbaugh, L.A.; Lindsell, C.J.; Shutter, L.A.; Szaflarski, J.P. Initial EEG predicts outcomes in a trial of levetiracetam vs. fosphenytoin for seizure prevention. Epilepsy Behav. 2012, 23, 280-284.

171. Kruer, R.M.; Harris, L.H.; Goodwin, H.; Kornbluth, J.; Thomas, K.P.; Slater, L.A.; Haut, E.R. Changing trends in the use of seizure prophylaxis after traumatic brain injury: A shift from phenytoin to levetiracetam. J. Crit. Care 2013, 28, e9-e13.

172. Szaflarski, J.P.; Sangha, K.S.; Lindsell, C.J.; Shutter, L.A. Prospective, randomized, single-blinded comparative trial of intravenous levetiracetam versus phenytoin for seizure prophylaxis. Neurocrit. Care 2010, 12, 165-172.

173. Inaba, K.; Menaker, J.; Branco, B.C.; Gooch, J.; Okoye, O.T.; Herrold, J.; Scalea, T.M.; Dubose, J.; Demetriades, D. A prospective multicenter comparison of levetiracetam versus phenytoin for early posttraumatic seizure prophylaxis. J. Trauma Acute Care Surg. 2013, 74, 766-771; discussion 771-773.

174. Pieracci, F.M.; Moore, E.E.; Beauchamp, K.; Tebockhorst, S.; Barnett, C.C.; Bensard, D.D.; Burlew, C.C.; Biffl, W.L.; Stoval, R.T.; Johnson, J.L. A cost-minimization analysis of phenytoin versus levetiracetam for early seizure pharmacoprophylaxis after traumatic brain injury. J. Trauma Acute Care Surg. 2012, 72, 276-281. 
175. Cotton, B.A.; Kao, L.S.; Kozar, R.; Holcomb, J.B. Cost-utility analysis of levetiracetam and phenytoin for posttraumatic seizure prophylaxis. J. Trauma 2011, 71, 375-379.

176. Kazerooni, R.; Bounthavong, M. Cost-effectiveness analysis of intravenous levetiracetam versus intravenous phenytoin for early onset seizure prophylaxis after neurosurgery and traumatic brain injury. ClinicoEcono. Outcomes Res. 2010, 2, 15-23.

177. Majdan, M.; Mauritz, W.; Wilbacher, I.; Brazinova, A.; Rusnak, M.; Leitgeb, J. Barbiturates use and its effects in patients with severe traumatic brain injury in five European countries. J. Neurotrauma 2013, 30, 23-29.

178. Ma, C.Y.; Xue, Y.J.; Li, M.; Zhang, Y.; Li, G.Z. Sodium valproate for prevention of early posttraumatic seizures. Chin. J. Traumatol. 2010, 13, 293-296.

179. Mountney, A.; Shear, D.A.; Potter, B.; Marcsisin, S.R.; Sousa, J.; Melendez, V.; Tortella, F.C.; $\mathrm{Lu}$, X.C. Ethosuximide and phenytoin dose-dependently attenuate acute nonconvulsive seizures after traumatic brain injury in rats. J. Neurotrauma 2013, 30, 1973-1982.

180. Ghanem, T.; Early, S.V. Vagal nerve stimulator implantation: An otolaryngologist's perspective. Otolaryngol. Head Neck Surg. 2006, 135, 46-51.

181. Englot, D.J.; Rolston, J.D.; Wang, D.D.; Hassnain, K.H.; Gordon, C.M.; Chang, E.F. Efficacy of vagus nerve stimulation in posttraumatic versus nontraumatic epilepsy. J. Neurosurg. 2012, 117, 970-977.

182. Shi, C.; Flanagan, S.R.; Samadani, U. Vagus nerve stimulation to augment recovery from severe traumatic brain injury impeding consciousness: A prospective pilot clinical trial. Neurol. Res. 2013, 35, 263-276.

183. Algattas, H.; Huang, J.H. Neurotrauma and repair research: Traumatic brain injury (TBI) and its treatments. Biomed. Eng. Comput. Biol. 2013, 5, 51-56.

(C) 2013 by the authors; licensee MDPI, Basel, Switzerland. This article is an open access article distributed under the terms and conditions of the Creative Commons Attribution license (http://creativecommons.org/licenses/by/3.0/). 